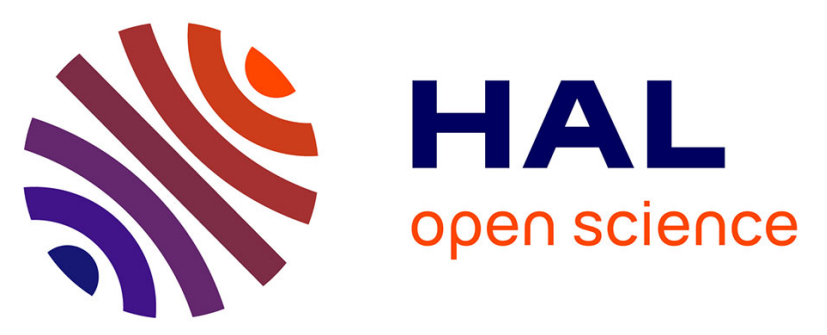

\title{
Single-route delaminated clay composites for efficient visible-light photo-mineralization of antibiotic-resistant bacteria and associated genes in water
}

Chidinma Ugwuja, Damilare Olorunnisola, Aemere Ogunlaja, Olawale Adelowo, Andreas Taubert, Gabriel Kolawole, Olumide Olukanni, Jessica Uwanibe, Adeyemi Kayode, Peter Hesemann, et al.

\section{To cite this version:}

Chidinma Ugwuja, Damilare Olorunnisola, Aemere Ogunlaja, Olawale Adelowo, Andreas Taubert, et al.. Single-route delaminated clay composites for efficient visible-light photo-mineralization of antibiotic-resistant bacteria and associated genes in water. Applied Catalysis B: Environmental, 2021, 292, pp.120143. 10.1016/j.apcatb.2021.120143 . hal-03284516

\section{HAL Id: hal-03284516 \\ https://hal.umontpellier.fr/hal-03284516}

Submitted on 28 Sep 2021

HAL is a multi-disciplinary open access archive for the deposit and dissemination of scientific research documents, whether they are published or not. The documents may come from teaching and research institutions in France or abroad, or from public or private research centers.
L'archive ouverte pluridisciplinaire HAL, est destinée au dépôt et à la diffusion de documents scientifiques de niveau recherche, publiés ou non, émanant des établissements d'enseignement et de recherche français ou étrangers, des laboratoires publics ou privés. 


\section{Single-Route Delaminated Clay Composites for Efficient Visible- Light Photo-mineralization of Antibiotic-Resistant Bacteria and Associated Genes in Water}

Chidinma G. Ugwuja ${ }^{\mathbf{1 , 2}}$, Damilare Olorunnisola ${ }^{\mathbf{1 , 2}}$, Aemere Ogunlaja ${ }^{\mathbf{2 , 3}}$, Olawale O. Adelowo ${ }^{\mathbf{4}}$, Andreas Taubert ${ }^{\mathbf{6}}$, Gabriel A. Kolawole ${ }^{\mathbf{1 , 2}}$, Olumide D. Olukanni' ${ }^{\mathbf{2},}$, Jessica N. Uwanibe ${ }^{\mathbf{3 , 5}}$, Adeyemi T. Kayode ${ }^{\mathbf{3 , 5}}$, Peter Hesemann ${ }^{\mathbf{8}}$, Despo Fatta-Kassinos, ${ }^{\mathbf{9}}$, Titus Msagati ${ }^{\mathbf{1 0}}$, Onikepe A. Folarin ${ }^{3,5}$, Clarke M. Stuart ${ }^{11}$, Emmanuel I. Unuabonah ${ }^{1,2 *}$

${ }^{1}$ Department of Chemical Sciences, Faculty of Natural Sciences, Redeemer's University, PMB 230, Ede, Osun State, Nigeria

${ }^{2}$ African Centre of Excellence for Water and Environmental Research (ACEWATER), Redeemer's University, PMB 230, Ede, 232101, Osun State, Nigeria

${ }^{3}$ Department of Biological Sciences, Faculty of Natural Sciences, Redeemer's University, PMB 230, Ede, Osun State, Nigeria

${ }^{4}$ Department of Microbiology, Faculty of Science, University of Ibadan, Oyo State, 200284, Nigeria

${ }^{5}$ African Centre of Excellence for Genomics of Infectious Diseases (ACEGID), Redeemer's University, PMB 230, Ede, Osun State, Nigeria

${ }^{6}$ Institute of Chemistry, University of Potsdam, D-14476 Potsdam, Germany

${ }^{7}$ Department of Biochemistry, Faculty of Natural Sciences, Redeemer's University, PMB 230, Ede, Osun State, Nigeria

${ }^{8}$ Institut Charles Gerhardt de Montpellier, Université de Montpellier-CNRS-ENSCM, Place Eugène Bataillon, 34090 Montpellier, France

${ }^{9}$ Department of Civil and Environmental Engineering and Nireas-International Water Research Centre, School of Engineering, University of Cyprus, PO Box 20537, 1678 Nicosia, Cyprus

${ }^{10}$ Nanotechnology and Water Sustainability Research Unit, University of South Africa, South Africa

${ }^{11}$ Department of Chemistry and BP Institute, University of Cambridge, Cambridge, UK

Corresponding author: Emmanuel I. Unuabonah

Email: unuabonahe@run.edu.ng 


\begin{abstract}
Drinking water contaminated with antibiotic resistance bacteria could result in loss of antibiotic effectiveness in humans, increased healthcare cost and ultimately death. New delaminated photocatalytic composite (DPC) has been prepared. DPC (2g) doped with $\mathrm{Cu} / \mathrm{Zn}$ kept multidrug resistant (MDR) E. coli and its sulphonamide resistance genes in contaminated water at $\log$ reduction $>6$ for $36 \mathrm{~h}$ in $1^{\text {st }}$ and $2^{\text {nd }}$ disinfection steps under visible-light using fixed-bed mode (downward flow). In contrast, fluoroquinolone resistance genes persisted in treated water after first disinfection step and were significantly reduced after the second disinfection step. No bacteria re-growth was observed in treated water stored in light/dark for 7 days. A 95\% photo-mineralisation of MDR E. coli and its genes in water was achieved via the release of superoxide radical (in dark and light). Shelf-life study of DPC vs nondelaminated photocatalytic composites over 7 month suggests that the former remained far efficient than the latter.
\end{abstract}

Keyword: E. coli; Photocatalyst stability; Antibiotic Resistance Genes; Antimicrobial Resistance Bacteria; Water

\title{
1.0 Introduction
}

There is growing interest in the presence of antibiotic resistant bacteria (ARB) and their associated resistance genes (ARGs) in treated and untreated water. They cause serious public health concern since they are able to transfer antibiotic resistance (AR) to bacteria in the environment and to humans. Antibiotic resistance is traceable to abuse of antibiotic drugs by humans, incomplete removal from wastewater treatment plants $[1,2]$ and from animal husbandry [3]. Several studies have shown the presence of ARB and ARGs in drinking water [4], surface waters [5], wastewater [1, 6] and irrigation water [7]. These ARB exchange antibiotic resistance encoding genetic material located on mobile genetic agents such as plasmids, transposons or integrons between microorganisms in a microbial community commonly referred to as horizontal gene transfer [8]. Ingesting water containing ARB and ARGs may likely alter the intestinal microbiota and this may lead to the proliferation of harmful pathogens in the human body and hence various diseases ranging from stomach disorder to colorectal cancer [9]. Therefore, the complete removal of ARB and their associated 
genes from food and the environment is now of global importance [10] with coalition of countries coming together to fight it such as the Joint Programming Initiatives on Antimicrobial Resistance (JPIAMR) https://www.jpiamr.eu/

Several attempts have been made to remove ARB and their associated genes from water: membrane technologies [11] advanced biological treatment [12] and various types of advanced oxidation processes including the use of UV-Chlorine [13], $\mathrm{UV} / \mathrm{H}_{2} \mathrm{O}_{2}$ [14], UV-C [15], Solar water disinfection (SODIS) [16], Fe-doped $\mathrm{ZnO}$ nanoparticles, $\mathrm{TiO}_{2}$ nanoparticles doped with cobalt and silver $[17,18], \mathrm{TiO}_{2}-\mathrm{rGO}$ [19], chitosan modified hybrid clay [20] and bacteriostatic clay [21]. The use of photocatalyst for water disinfection is gaining attention because of the ability of most photocatalyst to mineralise (photodegrade to $\mathrm{CO}_{2}$ and $\mathrm{H}_{2} \mathrm{O}$ ) the bacteria in water. Upon irradiation with light of proper wavelength, these photocatalysts generate reactive oxygen species (ROS) which degrade these bacteria in water $[\mathbf{2 2}, \mathbf{2 3}]$. These technologies have only reduced the amount of ARGs in the water even though they achieve as much as $99 \%$ removal of ARB. Moreover, it is sometimes the case that disinfection is not complete over time, allowing DNA repair and hence bacteria re-growth [24].

Although the use of "bare" (without support) nanoparticles may show promising disinfection performance, the challenges of particle aggregation that reduces the flow rate of water through them and the cost of recovering and reusing these nanoparticles will ultimately reduce their catalytic efficiency and limit their commercial utilisation. It is, therefore, essential to immobilise these "bare" nanoparticles on support materials to mitigate these challenges. Furthermore, even though several studies on photodisinfection of water have reported the use of the batch technique for water disinfection [25-28], there are a few reports on photodisinfection using the fixed-bed which truly mimic several large-scale water treatment systems and has further potential application in the development of photocatalytic point-of-use 
systems [29-32]. However, this study report the use of visible-light active clay-based photocatalyst for disinfection of water containing multidrug resistant E. coli (MDR E. coli). For the purpose of sustainability, cost and possible scalability, Kaolinite, a natural clay abundant in several parts of the world, is used to prepare the photocatalyst in this study. It is a further strategy of this work to increase the charge separation efficiency of $\mathrm{CuO}$ and $\mathrm{ZnO}$ (semiconductors) and improve not just their photogradation ability but also their photomineralization efficiency. It is expected that Kaolinite acting as a support, will limit photocorrosion of these semiconductors making it easier to recover them from solution after every photocatalytic process $[33,34]$. This report, represent one of the few reports on the use of clay-based photocatalyst for disinfection of ARB contaminated water which in our previous study prove to more difficult than disinfection of non-antibiotic resistant strains of bacteria in water. More specifically, is the aim of this study to achieve high photo-mineralization of ARBs and ARGs (conversion to $\mathrm{CO}_{2}$ and $\mathrm{H}_{2} \mathrm{O}$ ) in water.

Visible-light active clay-based photocatalysts were therefore, developed from urea-promoted delamination and functionalisation of Kaolinite clay with semiconductors $(\mathrm{ZnO}$ and $\mathrm{CuO})$ in a single step via microwave heating, eliminating the conventional intercalation stage. The addition of carica papaya seeds into these photocatalytic composites is to introduce a carbon interlayer pathway which hinders fast recombination of electron-hole pairs and invariably extend their absorption range in the visible-light, improving their photocatalytic performance [35]. In characterising these photocatalytic composites, data were obtained from FE-SEM, XRD, EDX, ICP-MS, ATR-FTIR, UV/Vis-DRS and EPR. All photocatalytic composites prepared in this study were used to photo-mineralise MDR E. coli and its associated resistance genes in water via a fixed-bed mode. Results obtained indicates that the new photoactive composites are efficient and sustainable with a high level of photo-mineralisation (up to 93\%) with no re-growth of this bacteria in both light and dark conditions (in the incubator at $37{ }^{\circ} \mathrm{C}$ ) 
after treated water samples were left standing for 7 days. DPC prepared via microwave assisted method showed very good stability even after seven months of storage in different conditions in contrast with results obtained from DPC prepared with furnace. These results illustrate the potential of these materials as efficient and sustainable new photoactive composites, with high possibilities for use in the development of point-of-use water treatment device that could be used for disinfection of drinking water.

\subsection{MATERIALS AND METHODS}

\subsection{Reagents/ Materials}

Kaolinite clay was purified according to Adebowale et al. [36]. Carica papaya seeds were obtained from different markets within Ede, Osun State, Nigeria, sun-dried and crushed with mortar and pestle. The crushed seeds were subsequently packed into airtight containers for further use. Zinc Chloride $\left(\mathrm{ZnCl}_{2} \cdot 6 \mathrm{H}_{2} \mathrm{O}\right)$ and absolute ethanol (95\% purity) were purchased from Sigma Aldrich Limited while Copper Chloride $\left(\mathrm{CuCl}_{2}\right)$ was acquired from (Surechem LTD), Nutrient Agar (Oxoid), and Urea was purchased from (Saarchem). All chemical reagents were used without further purification. Sterile water (Millipore water dispensed with $0.02 \mu \mathrm{m}$ membrane filter and subsequently sterilized in an autoclave at $121^{\circ} \mathrm{C}$ for $15 \mathrm{~min}$ ) was used in this study. The characteristics of the water include: $\mathrm{pH}=6.9$, turbidity $=0.8 \mathrm{NTU}$, total dissolved solid $=28.41 \mathrm{mg} / \mathrm{L}$, and conductivity $=47.26 \mu \mathrm{S} / \mathrm{cm}$.

\subsection{Synthesis and characterisation of Composite Materials.}

$10 \mathrm{~g}$ of Urea was dissolved in a mixed solvent of ethanol and water in a ratio of $3: 1$. The mixture was sonicated for $15 \mathrm{~min}$ using a probe sonicator. Thereafter, $5 \mathrm{~g}$ of Kaolinite was added and sonicated for another $15 \mathrm{~min}$. The suspension was then magnetically stirred for 30 min following the addition of different weights of crushed Carica papaya seeds ( $5 \mathrm{~g}$ ), $\mathrm{CuCl}_{2}$ 
and $\mathrm{ZnCl}_{2}\left(20 \mathrm{~g}\right.$ each), and $\mathrm{ZnCl}_{2} / \mathrm{CuCl}_{2}(20 \mathrm{~g} / 10 \mathrm{~g})$ as reported in our previous w ork [22]. A 0.1 $\mathrm{M} \mathrm{NaOH}$ solution $(10 \mathrm{~mL})$ was added to all slurries. The mixtures were then dried in an oven at $100{ }^{\circ} \mathrm{C}$ for $24 \mathrm{~h}$ and transferred to a laboratory microwave furnace for calcination at $500{ }^{\circ} \mathrm{C}$ for 7 min under $\mathrm{N}_{2}$ atmosphere. Afterwards, the dark products were allowed to cool to room temperature, washed with sterile water until they attained a neutral $\mathrm{pH}$. The solid samples were oven-dried at $100{ }^{\circ} \mathrm{C}$, crushed gently and stored in an airtight container for further use. The delaminated-doped photocatalytic composite material prepared with $\mathrm{ZnCl}_{2}$ is identified in this work as ' $d$ - $\mathrm{Zn}$ doped', that prepared with $\mathrm{CuCl}_{2}$ as ' $d$-Cu doped' and that prepared with $\mathrm{CuCl}_{2}+\mathrm{ZnCl}_{2}$ as ' $d-\mathrm{Cu} / \mathrm{Zn}$ doped'.

\subsection{Characterisation of Composite Materials}

Materials prepared in this study were characterized using Field Emission Gun-Scanning Electron Microscopy (FEG-SEM, TESCAN MIRA3) coupled with an electron dispersive xray (EDX) spectrometer, powder x-ray diffraction (PXRD), elemental analyser, fourier transform infrared (FTIR) spectrophotometer with universal attenuated total reflectance (ATR) sampling accessory, thermal gravometric analyser/differential scanning calorimetry, UV/Vis diffuse reflectance spectroscopy, fluorescence spectrophotometer and electron paramagnetic resonance. Treated and untreated water samples were characterized with inductively coupled plasma-mass spectrometer (ICP-MS) and UV/Vis spectrophotometer. Details of these equipment are described in the SI document (section S1).

\subsection{E. coli Isolation and Antimicrobial Susceptibility Testing}

The E. coli strain was obtained from a faecal taken sample from a pig farm in Ogbomoso, Nigeria. One gram $(1 \mathrm{~g})$ of the faecal sample was suspended in $9 \mathrm{ml}$ of $0.85 \%$ sterile saline solution and left to stand for $4 \mathrm{~h}$ after which a loop full was streaked on Eosin Methylene Blue (EMB) agar plates which was incubated for $24 \mathrm{~h}$. Colonies appearing with a green metallic 
sheen on the plates were sub-cultured and purified on fresh EMB agar plates till pure homogeneous colonies were obtained.

To confirm susceptibility of the $E$. coli strain to selected antibiotics, the disc diffusion method. Isolated colonies from an overnight culture of the strain were suspended in normal sterile saline water $(0.85 \%)$ and standardised to conform to 0.5 McFarland turbidity standard. The inoculum was spread on the surface of Mueller Hinton agar (MHA) using a sterile swab stick. Discs (Oxoid) of antibiotics used for the susceptibility test include ceftazidime $(30 \mu \mathrm{g})$, amoxycillin/clavulanate $(20 / 10 \mu \mathrm{g})$, cefpodoxime $\quad(10 \mu \mathrm{g}), \quad$ aztreonam $\quad(30 \mu \mathrm{g})$, sulphamethoxazole/trimethoprim $(23.75 / 1.25 \mu \mathrm{g})$, ciprofloxacin $(5 \mu \mathrm{g})$, Gentamicin $(10 \mu \mathrm{g})$, Cefepime $(30 \mu \mathrm{g})$, Ertapenem $(10 \mu \mathrm{g})$. These discs were placed aseptically on MHA plates previously inoculated with saline suspensions of the test bacteria. The plates were incubated overnight at $37{ }^{\circ} \mathrm{C}$, and zones of growth inhibition around each disc were measured and interpreted using the Clinical and Laboratory Standards Institute (CLSI) zone diameter standard [37]. The isolate showed resistance to all the 9 antibiotics which belong to four different classes of antibiotics and is hence confirmed as a multidrug resistance (MDR) strain of $E$. coli. These antibiotics were selected because they are commonly purchased over the counter and used in West Africa. Methods for isolation and molecular characterization of antibiotic resistance genes from MDR E. coli used in this study are well described in section S3.0 in the supporting information document.

\subsection{Photo-disinfection Under Visible-light Irradiation}

A sample of sterile water was initially cultured with a selective agar (Eosin Methylene Blue, EMB), to ensure the absence of the target organism in the water. Pure culture of MultidrugResistant E. coli (MDR E. coli) grown overnight in nutrient broth at $37{ }^{\circ} \mathrm{C}$ was harvested and added to sterile water to achieve the desired concentration of bacteria suspension. Bacteria 
load was quantified by measuring the optical density at $600 \mathrm{~nm}\left(\mathrm{OD}_{600}\right)$ using a UV/Vis spectrophotometer. Absorbance value obtained was converted to concentration using Agilent biocalculator https://www.chem.agilent.com/store/biocalculators/calcODBacterial.jsp which is related to the number of bacteria colony-forming units per millilitre. The equivalent amount of $2.16 \times 10^{7}(\mathrm{cfu} / \mathrm{mL})$ was obtained as the initial concentration of MDR E. coli.

The fixed-bed mode of water treatment was employed in this study. In this fixed-bed mode, a transparent glass column of dimension $400 \times 10 \mathrm{~mm}$, initially sterilised at $160{ }^{\circ} \mathrm{C}$ for $2 \mathrm{~h}$ was loaded with a fixed weight $(2.0 \mathrm{~g})$ of each of the prepared photocatalytic composite material. Prior to this, photocatalytic composite materials were sterilised by dispersing them in $70 \%$ ethanol and dried to constant weight at $105{ }^{\circ} \mathrm{C}$. Afterwards, the packed glass column was primed by passing in $400 \mathrm{~mL}$ of sterile water. Subsequently, $2.16 \times 10^{7} \mathrm{cfu} / \mathrm{mL}$ of the target organism (MDR E. coli) in sterile water was passed through the packed column at a flow rate of $8 \mathrm{~mL} / \mathrm{min}$ under light from laboratory fluorescence lamps. The spectrum for laboratory fluorescence lamps is shown in Fig. S1 (supporting information document). This was collected with an Ocean Optics USB 2000+ Spectrometer through a spectral range of 180-880 $\mathrm{nm}$.

Samples for analysis were collected after every $1 \mathrm{~h}$ and checked for inactivation of inoculated bacteria using the pour plate method. Briefly, $20 \mathrm{~mL}$ of molten EMB was added to Petri dishes containing $1 \mathrm{~mL}$ of the treated water samples followed by gentle swirling to mix the nutrient agar and treated water samples. The sample-agar mix was allowed to solidify, and the plates were incubated at $37^{\circ} \mathrm{C}$ for $18-24 \mathrm{~h}$ before being observed for the growth of bacterial colonies which were counted to obtain the breakthrough time of water disinfection (the time it takes to observe the first colony of bacteria in the treated water). 
To ascertain the level of photo-mineralisation of the bacteria cells by these photocatalytic composites, the Teledyne Tekmar Total Organic Carbon fusion analyser was used to measure (indirectly) the amount of the bacteria cells that were converted to $\mathrm{CO}_{2}$ and $\mathrm{H}_{2} \mathrm{O}$ during photocatalysis via the UV/persulfate oxidation method. The percentage photo-mineralisation was calculated using the equation (1)

$\%$ Photo - mineralization $=\frac{T O C_{o}-T O C_{e}}{\text { TOC }_{o}} \times 100$

Where $\mathrm{TOC}_{\mathrm{o}}$ is the total organic carbon of bacteria cells in water before treatment and $\mathrm{TOC}_{\mathrm{e}}$ the total organic carbon of bacteria cells/transformed products in treated water.

\subsection{Removal of Antibiotic Resistance Genes}

It is anticipated that after the treatment of water containing the target organisms and their associated genes, the amount of total genomic DNA (gDNA) in the treated water should be minimal or absent. To check for this, PCR amplification of selected antibiotic resistance genes in the MDR E. coli contaminated water samples and treated water samples was done. However, due to the low concentration of the gDNA found in the treated water, $1 \mathrm{~L}$ of the treated water was used for gDNA extraction [19]. The method used for DNA extraction from water and primers used for identification of antibiotic resistance genes are fully described in section S2.0 (supporting information document).

\subsection{Analysis of Bacterial Membrane Lyses}

It is known that metal toxicity and the release of reactive oxygen species from photocatalysts can lead to bacteria cell death. To examine the possibility of the release of metals and reactive oxygen species from the prepared photocatalysts in this study:

(a) sterile water passed through a $2 \mathrm{~g}$ of each of the photocatalyst (delaminated composites) in transparent glass beds, and the amount of metals $(\mathrm{Cu}$ and $\mathrm{Zn})$ released into treated water were 
determined from samples collected after specific time intervals $(1,6,12,18,30 \mathrm{~h})$ using Inductively Coupled Plasma-Mass Spectrometer (ICP-MS)

(b) In another experiment, MDR E. coli contaminated water was used in place of sterile water, and the amount of metals released into treated water samples were also determined. Besides, the amount of $\mathrm{Ca}^{2+}$ in the treated water samples was also measured as a means of tracking bacteria cell death. Concentrations of $\mathrm{Ca}^{2+}$ were determined using ICP-MS and at similar time intervals as in (a).

(c) Delaminated composites prepared in this study are analogues of photocatalysts used in our previous study [22] which released singlet oxygen as their main reactive oxygen species. We, therefore, decided to analyse for the release of superoxide (as a precursor for the release of singlet oxygen). The release of superoxide radicals $\left(\boldsymbol{O}_{2}^{-}\right)$from the delaminated composites were estimated using nitro blue tetrazolium (NBT). NBT shows maximum absorbance at 259 $\mathrm{nm}$, however in the presence of superoxide radicals, it will be converted to monoformazan and diformazan. Therefore, the production of superoxide radicals was estimated by monitoring the degradation of NBT using UV/Vis spectroscopy. The method involves the addition of $5 \mathrm{~mL}$ of $100 \mathrm{mg} / \mathrm{L} \mathrm{NBT}$ to $20 \mathrm{mg}$ delaminated photocatalytic composite material in the dark. This mixture is then placed in the UV/Vis equipment sample holder, set to kinetic mode and data was collected every 30 seconds. For the experiment carried out in the light, the same laboratory light conditions utilised for photocatalysis in this study (section 2.5) was used. However, the sample was withdrawn from the UV/Vis equipment after every 30 second and held in the light for 30 seconds before every reading was taken. Data were taken at $600 \mathrm{~nm}$ using the UV/Vis spectrophotometer.

\subsection{Bacteria Regrowth Study}

Some bacteria have been known to enter a viable but not culturable (VBNC) state during or after disinfection of water (a condition in which they may still be alive but cannot be identified 
in cultivation media) while still having the ability to regrow and be reactivated during storage and distribution of the treated water [38]. It is therefore, necessary to carry out a re-growth study on photo-disinfected water since treated water is held in reservoirs and not immediately distributed. In this work, bacteria re-growth study was carried out following a slightly modified protocol as earlier discussed in section 2.4. Samples $(50 \mathrm{~mL})$ collected at various time intervals were divided into two portions and kept in sterile sample bottles. While one portion was left in an incubator at $37^{\circ} \mathrm{C}$ to give necessary recuperation time for likely injured bacteria, the other portion was left on the laboratory bench in a transparent bottle. A $1 \mathrm{~mL}$ sample is withdrawn from the stored sample containers after every $24 \mathrm{~h}$ for 7 days, and the presence of target bacteria cells was determined using EMB.

\subsection{Photocatalyst Stability Test}

One crucial factor that will determine the future of visible-light photocatalysts is their shelflife. To determine this, we studied the impact of storage time and conditions on the stability of the best photocatalytic composite $(d$-Cu/Zn doped) in comparison with its non-delaminated analogue $(f-\mathrm{Cu} / \mathrm{Zn}$ doped) previously prepared [22]. $7 \mathrm{~g}$ each of these photocatalytic composites was stored under three different conditions: Light (transparent glass bottle under fluorescent lamps in the laboratory), Amber (using amber coloured bottles placed under fluorescent lamps in the laboratory) and dark (in the absence of light in a glass bottle lined with aluminium foil). All samples were stored for seven months. During the period of storage, $250 \mathrm{mg}$ of each photocatalytic material was withdrawn from stored samples and used for the degradation of $50 \mathrm{~mL}$ of $10 \mathrm{mg} / \mathrm{L}$ Rhodamine $\mathrm{B}(\mathrm{RB})$ dye at the end of each month. However, the photodegradation of the dye was carried out under visible-light (using fluorescent lamp) and in the dark for $120 \mathrm{~min}$. Aliquots $(2 \mathrm{~mL})$ were withdrawn at specific time intervals. The composites were separated through $0.45 \mu \mathrm{m}$ polytetrafluoroethylene (PTFE) syringe filters. The residual dye in solution was quantified using Shimadzu UV-VIS 1650 PC 
spectrophotometer at a maximum absorption wavelength of $554 \mathrm{~nm}$. The degree of photodegradation of the dye $(\mathrm{R})$ was calculated as:

$R(\%)=\frac{\mathrm{Co}-\mathrm{Ce}}{\mathrm{Co}}$

Where $C_{o}$ and $C_{e}$ represent the initial and final dye concentrations in water, respectively. Kinetic data from degradation studies were fitted to the first-order kinetic model equation commonly used for heterogeneous catalytic processes [39].

$$
\operatorname{In}\left(\frac{c t}{c o}\right)=-k t
$$

$\mathrm{C}_{\mathrm{o}}$ and $\mathrm{C}_{\mathrm{t}}$ are the concentration values $\mathrm{RB}$ dye at time zero and at time $\mathrm{t}$ respectively, and $\mathrm{k}$ is the slope of the linear plot $\operatorname{In}\left(\frac{C t}{C o}\right)$ against time $\mathrm{t}$, the first-order rate constant.

\subsection{RESULTS AND DISCUSSION}

\subsection{Physicochemical Analysis}

It is essential to verify the physical characteristics and chemical compositions of the composite materials prepared, their optical properties and their morphologies to give basic information on their photocatalytic nature. Based on this, several analyses were carried out.

\subsubsection{Scanning Electron Microscopy Images}

Scanning Electron Microscopy (SEM) analysis was used to understand the morphology of particles of the prepared delaminated photocatalytic composites. The SEM images of all three composite materials show materials that are sheet-like and dotted with some grains resulting from partial delamination of kaolinite (Fig 2A-C). The presence of these sheet-like structures in these composites might not be unconnected with the use of sonicator during the preparation of these composites. It is reported that ultrasonic irradiation from sonication contributes to the delamination of layered materials $[40,41]$. However, the $d$-Cu/Zn doped composite sheets 
have what appear to be "bumps" (see inset in Fig. 2C) that were analysed to contain $\mathrm{Cu}$ and Zn (with other elements in minor quantity) through Energy Dispersive X-ray analysis (SI X).
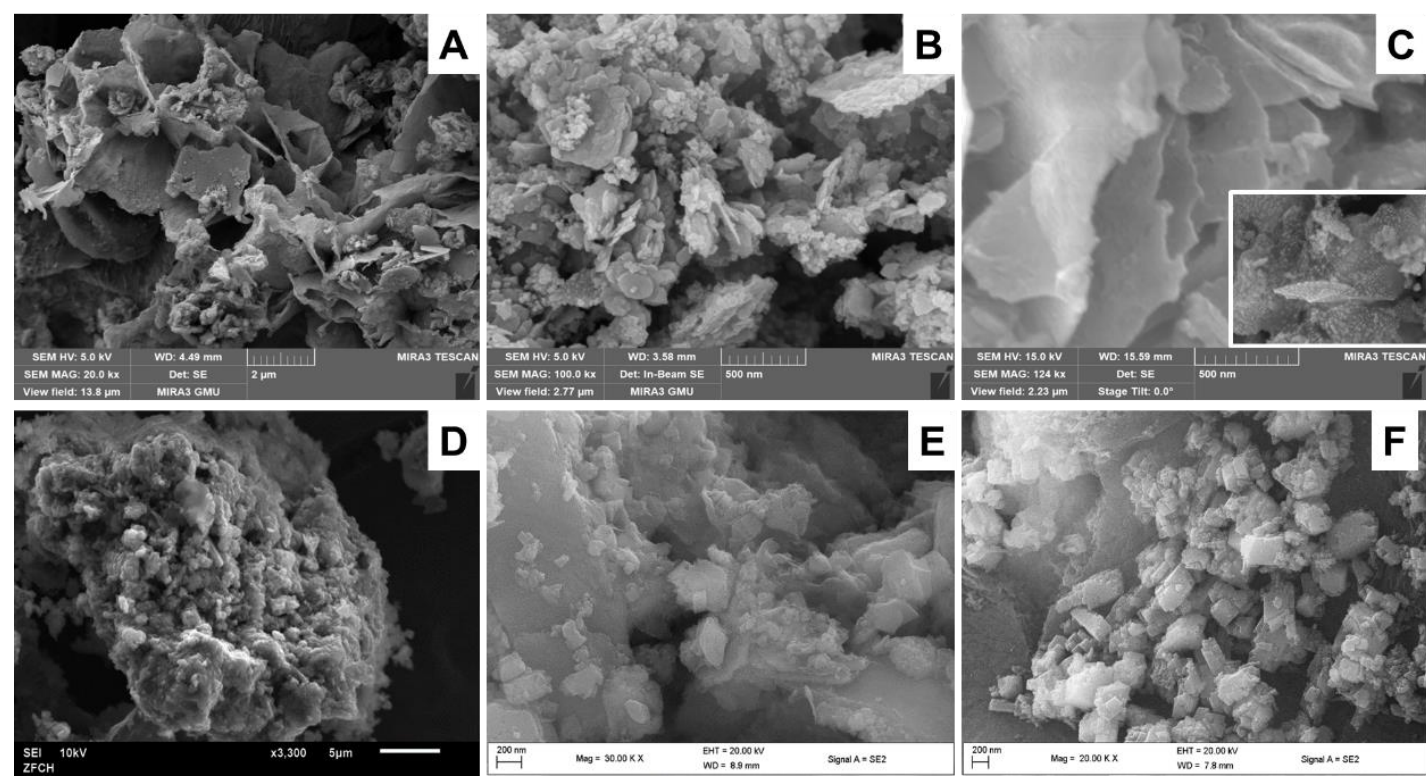

Fig. 2: Scanning Electron Microscope Images of (A) $d$-Zn doped (B) $d$-Cu doped and (C) $d$ $\mathrm{Cu} / \mathrm{Zn}$ doped (D) $f$-Zn doped (E) $f$-Cu doped (F) $f$-Cu/Zn doped Photocatalytic Composites (Figs. 2D-F were reproduced from [22])

Generally, the morphologies of particles in this study are in contrast with those of its nondelaminated analogues prepared in a previous study that showed composites that were aggregated [22] as can be seen in Fig. 2D-F.

Fig 3A represents the ATR-FTIR spectra of the prepared delaminated composite materials. The $d$ - $\mathrm{Cu}$ doped and $d$ - $\mathrm{Cu} / \mathrm{Zn}$ doped composite materials show the $-\mathrm{OH}$ stretching band of clinoatacamite at 3315 and $3447 \mathrm{~cm}^{-1}$ respectively and $-\mathrm{OH}$ stretching frequency at $3443 \mathrm{~cm}^{-1}$ (for $d$-Cu doped composite). Peaks at 3307 and $3361 \mathrm{~cm}^{-1}$ (for $d-\mathrm{Cu} / \mathrm{Zn}$ doped composite) are assigned to atacamite $\left(\mathrm{Cu}_{2}(\mathrm{OH})_{3} \mathrm{Cl}\right)$ mineral phases [42]. However, a similar peak for $d-\mathrm{Zn}$ doped composite which is broad and centred around $3324 \mathrm{~cm}^{-1}$ indicates the presence of the hydroxyl-stretching frequency of zincian paratacamite $\left.(\mathrm{Cu}, \mathrm{Zn})_{2}(\mathrm{OH})_{3} \mathrm{Cl}\right)(\mathbf{R E F})$. The peak centred around $1568 \mathrm{~cm}^{-1}$, which appears in the spectrum of both $d-\mathrm{Zn}$ doped and $d-\mathrm{Cu} / \mathrm{Zn}$ 
doped composites, represents the amide I band while the peak at $1631 \mathrm{~cm}^{-1}$ observed in the spectrum for $d$-Cu-doped material is assigned to the $\mathrm{N}-\mathrm{H}$ bending vibration [43].

In the fingerprint region, the $1027 \mathrm{~cm}^{-1}$ peak in all the three composites is assigned to the $\mathrm{Si}-\mathrm{O}$ band from kaolinite [44, 45]. Octahedrally coordinated $\mathrm{Al}\left[\mathrm{AlO}_{6}\right]$ is seen in all three composites at $510 \mathrm{~cm}^{-1}$ respectively while the peaks at 796 and $697 \mathrm{~cm}^{-1}$ in the composites are assigned to Si-O stretching and bending modes of quartz $[44,46]$. The hydroxyl deformation vibrations observed at $984,914,860$ and $695 \mathrm{~cm}^{-1}$ are typical of atacamite phase [47].

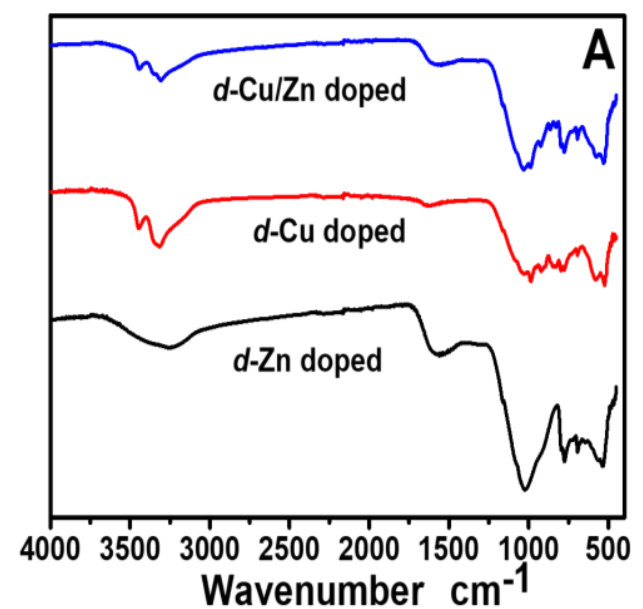

Fig. 3: (A) ATR-FTIR absorption spectra (B) X-ray Diffraction patterns of prepared delaminated composites

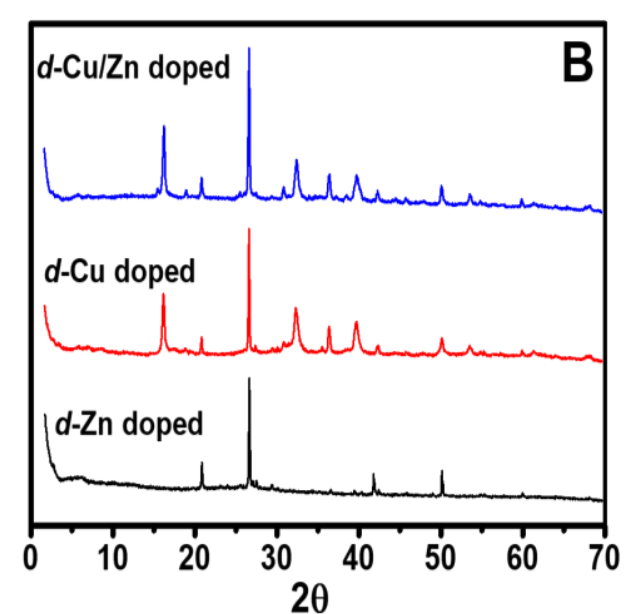

The XRD spectra for the various prepared delaminated composites are shown in Fig. 3B. The $d$-Zn doped composite shows four distinct peaks: $2 \theta$ 20.9, 26.7, 42.2 and 50.2 ${ }^{\circ}$ (JCPDS 461045), which all depict the presence of quartz in the composite introduced from kaolinite. The $d$-Cu doped and $d$-Cu/Zn doped composites show similar quartz peaks. However, $d$-Cu doped composite shows the presence of orthorhombic atacamite crystal phase at $2 \theta 16.2(011), 32.4$ (201), 39.7 (202), 50.1 (232), and 53.6 (312) having the chemical formula of $\left[\mathrm{Cu}_{2}(\mathrm{OH})_{3} \mathrm{Cl}\right]$ (JCPDS 25-0269). In the case of $d$-Cu/Zn doped composite, there is the presence of rhombohedra atacamite mineral (zincian paratacamite) at 16.2 (200), 30.7 (220), 32.4 (022), $39.7(222), 50.1(-333)$ and $53.5^{\circ}(040)$ with the chemical formula of $\left[(\mathrm{Cu}, \mathrm{Zn})_{2}(\mathrm{OH})_{3} \mathrm{Cl}\right]$. 
These are all similar to crystal phases previously reported for non-delaminated analogues of these composites [22]. Nevertheless, in our previous study, non-delaminated $\mathrm{Cu}-$ and $\mathrm{Cu} / \mathrm{Zn}$ doped composites showed the presence of tenorite $(\mathrm{CuO})$ at $2 \theta 35.5,38.7$ and $66.2^{\circ}$ [22] which is absent in the delaminated analogues ( $d$-Cu doped and $d$ - $\mathrm{Cu} / \mathrm{Zn}$ doped composites). Similarly, there is the absence of the $\mathrm{CuCl}$ (nantokite) phase previously seen in nondelaminated $\mathrm{Cu}$-doped composite at $2 \theta 28.4^{\circ}$ [22]. In any case, there is the development of new peaks in the $d-\mathrm{Cu}$ and $d-\mathrm{Cu} / \mathrm{Zn}$ doped composites at $2 \theta 30.8,36.4,42.3,53.6$ and $61.5^{\circ}$ (Fig. 3B) which belongs to the 110, 111, 200, 211 and 220 set of planes respectively of Cuprite- $\mathrm{Cu}_{2} \mathrm{O}$ (JCPDS 05-0667) [48, 49]. This indicates a reduction of $\mathrm{Cu}$ in the composite from +2 to +1 oxidation state in the $d$-Cu doped composite. It is, therefore, suggested that delamination of kaolinite with urea in the presence of $\mathrm{CuCl}_{2}$ could result in the formation of cuprite $\left(\mathrm{Cu}_{2} \mathrm{O}\right)$ rather than a $\mathrm{CuO}$ crystal phase as found in the non-delaminated form.

Results from both ATR-FTIR and XRD analysis confirm the formation of atacamite and paratacamite in the delaminated composites as well as a cuprite phase in the $d-\mathrm{Cu}$ and $d-\mathrm{Cu} / \mathrm{Zn}$ doped composites. The development of these secondary mineral phases is known to enhance photoactivity by extending optical absorption to wavelengths in the visible region and reduce electron-hole recombination rate [50].

\subsubsection{Electron Paramagnetic Resonance}

To further characterise these composites, electron paramagnetic resonance (EPR) analysis was carried out. Figure Fig 4 shows the EPR spectra of these composites. 

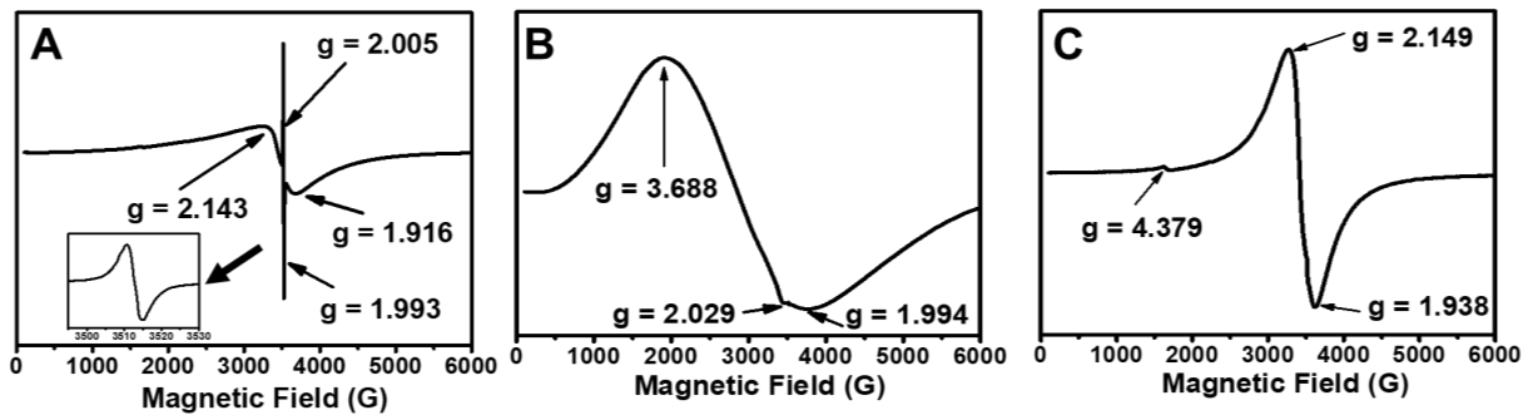

Fig. 4: EPR spectra of (A) $d$-Zn doped (B) $d$-Cu doped and (C) $d$-Cu/Zn doped composites.

From the EPR spectra of $d$-Zn doped composite (Fig. 4A), the presence of a six coordinated Ti $\left[\mathrm{TiO}_{6}\right]$, oxygen vacancies in $\mathrm{ZnO}\left(\mathrm{V}_{\mathrm{O}}\right), \mathrm{Zn}$ vacancy $\left(\mathrm{V}_{\mathrm{Zn}}\right)$ and partially filled $\mathrm{Zn}$-vacancies due to $\mathrm{H}^{+}$implantation $\left(\mathrm{V}_{\mathrm{Zn}}^{2-}-\mathrm{H}^{+}\right)$in the composite are represented by $\mathrm{g}$ values $1.916,1.993$, 2.005 , and 2.143, respectively [51,52]. The g values of 1.994 and 2.029 found in $d$-Cu doped composites (Fig. 4B) signify the presence of singly ionised oxygen vacancies and $\left[\mathrm{Cu}_{2}(\mathrm{OH})_{3} \mathrm{Cl}\right]$ (atacamite) in the composite. In addition, the signal at g-value of 3.688 suggests the presence of $\mathrm{Cu}$ ions present in a unit cell of the composite [53]. However, for $d-\mathrm{Cu} / \mathrm{Zn}$ doped composite (Fig. 4C), there is the loss of $\mathrm{Zn}$-vacancies $(\mathrm{g}=2.005)$ arising from the impact of the presence of $\mathrm{Cu}$ used in the preparation of the composite. The presence of $\mathrm{Cu}$ has been shown to weaken the EPR signal of $\mathrm{ZnO}$ vacancies when they are simultaneously present in a composite [54] even though the presence of partially filled Zn-vacancies in this composite is still seen at $\mathrm{g}=2.149$ with increased intensity. These partially filled Zn-vacant positions in the composites are known to act as non-radiative recombination centres in the particles [52]. Nonetheless, these defects are known to improve charge separation that leads to longer excited-state lifetimes and hence improved photocatalytic activity [55]. However, the very weak signal at $\mathrm{g}=4.379$ is typical of $\mathrm{d}^{5}$ ion of $\mathrm{Fe}^{3+}[56]$ which is a confirmation of its presence in the composite as an impurity as is seen in Fig. $\mathbf{6}$. 


\subsubsection{Optical Properties}

Fig. 5A shows that all the delaminated composites absorb light in the visible region (visiblelight active) with both $d$ - $\mathrm{Zn}$ and $d$-Cu/Zn doped composites showing broad absorption band around a wavelength of $400 \mathrm{~nm}$. This suggests that the $\mathrm{Cu}^{2+}$ species introduced into this composite $(d-\mathrm{Cu} / \mathrm{Zn}$ doped $)$ may have been reduced to $\mathrm{Cu}^{+}$, a $\mathrm{d}^{10}$ specie like $\mathrm{Zn}^{2+}$, presumably because of the use of urea in the delamination of kaolinite. This observation is further corroborated by the observance of cuprite $\left(\mathrm{Cu}_{2} \mathrm{O}\right)$ peak in the XRD pattern of the composite (Fig. 3B) and may account for its similar spectrum with $d$-Zn doped composite (Fig. 5A).
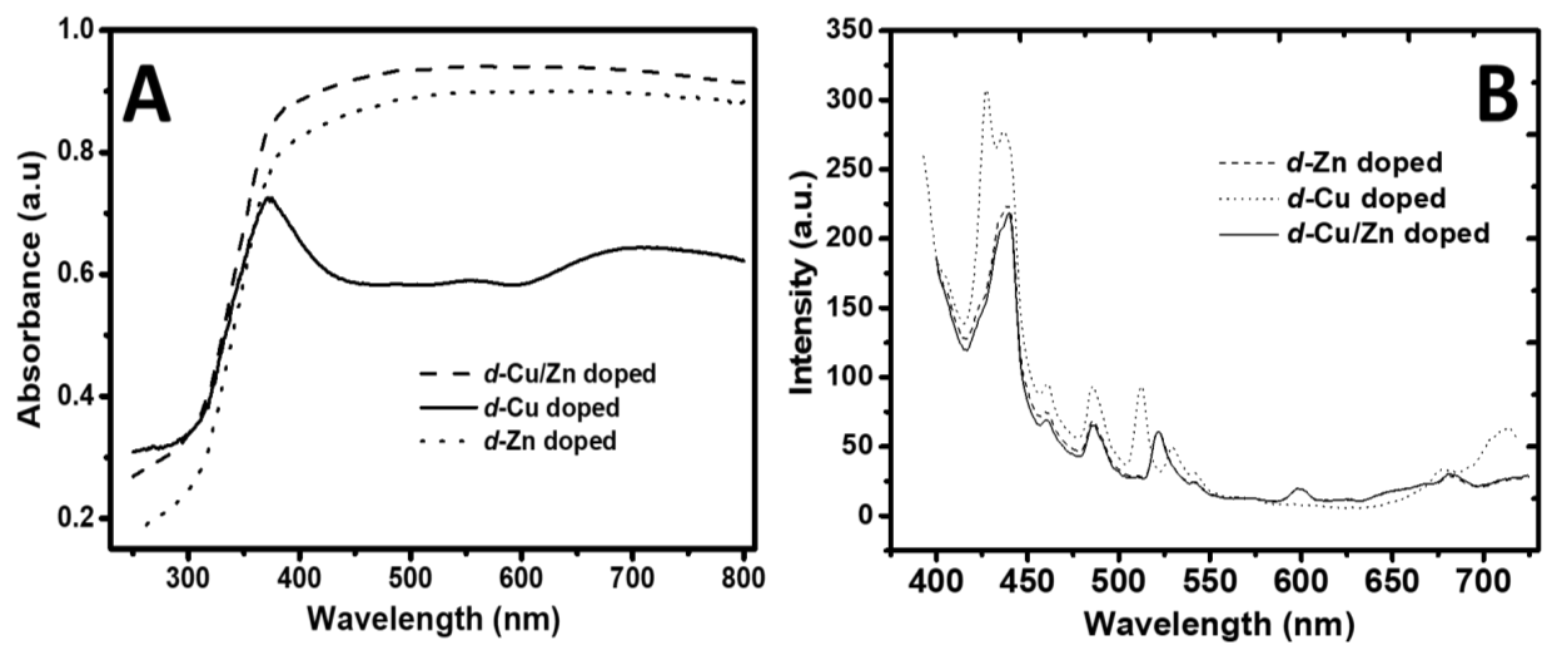

Fig. 5: (A) UV/Vis DRS spectra of delaminated composites (B) Photoluminescence spectra of delaminated composites @ excitation wavelength of $380 \mathrm{~nm}$

The d-Cu doped composite show three distinct bands at 374, 555 and $701 \mathrm{~nm}$. The spectrum for $d$-Cu doped composite is typical of a Jahn-Teller distorted $\mathrm{Cu}^{2+}-\mathrm{d}^{9}$ system, generating three distinct bands due to $d-d$ transition [57].

The room temperature photoluminescence spectra of the various delaminated composites are shown in Fig. 5B. The spectra show bands that indicate that all delaminated composites are active in the visible-light region with the $d$-Cu doped giving a band-edge violet emission at $427 \mathrm{~nm}$ and a second emission at $542 \mathrm{~nm}$ resulting from singly ionised oxygen vacancy of 
$\mathrm{Cu}_{2} \mathrm{O}$ [48]. This confirms the result from UV/Vis DRS analysis in Fig. 5A. The green band at $524 \mathrm{~nm}$ is related to various defects in the crystal lattice of the $d$-Cu doped composite arising from copper vacancies, interstitial copper, interstitial oxygen, oxygen vacancy etc. These oxygen vacancies reduce photo-induced electron-hole recombination by introducing new energy levels that reduce the band edge [58]. However, the bands presented by $d$-Zn doped and $d-\mathrm{Cu} / \mathrm{Zn}$ doped composites are similar (Fig. 5B) supporting our previous deduction of the reduction of $\mathrm{Cu}^{2+}$ in $d-\mathrm{Cu} / \mathrm{Zn}$ doped composite to $\mathrm{Cu}^{+}$, a d ${ }^{10}$ specie like $\mathrm{Zn}^{2+}$. The bands at 438, 460, 486 and $521 \mathrm{~nm}$ are caused by the transitions of excited electrons from the level of $\mathrm{Zn}_{\mathrm{i}}$ (interstitial $\mathrm{Zn}$ ) to the valence band, deep level defect emission associated with oxygen vacancies in $\mathrm{ZnO}$ lattices, a transition between the $\mathrm{V}_{\mathrm{O}}$ (oxygen vacancy) and $\mathrm{O}_{\mathrm{i}}$ (interstitial oxygen), and lattice defects related to oxygen and zinc vacancies respectively [59]. The band at 521 is related to the various kinds of defects in $\mathrm{ZnO}$ [59].

\subsubsection{Energy Dispersive X-Ray (EDX) and Thermogravimetric Analysis}

Figure 6 shows the elemental composition of the three delaminated composite materials. Looking closely at Fig. 6A, it is observed that the amount of $\mathrm{Al}$ and $\mathrm{Si}$ in the $d$-Cu doped composite decreased almost to an insignificant value due to extraction from $\mathrm{NaOH}$ used in its preparation. The EDX profile further suggests that the percentage weight of $\mathrm{Cu}$ loading in the $d$-Cu doped composite is higher than the $\mathrm{Zn}$ loading in the $\mathrm{Zn}$-doped composite. The same trend is observed with $d$-Cu/Zn doped composite. The higher $\mathrm{Cu}$ loading is due to its smaller ionic radius that increases the magnitude of its interaction with the carbon surface when compared with $\mathrm{Zn}$ [60]. The presence of carbon in the composites is established with elemental analysis, as shown in Fig. 6B. A significant amount of nitrogen is seen in all three composites (Fig. 6B) in confirmation of earlier FTIR results suggesting the presence of amide I band and N-H vibrations in the composites. 

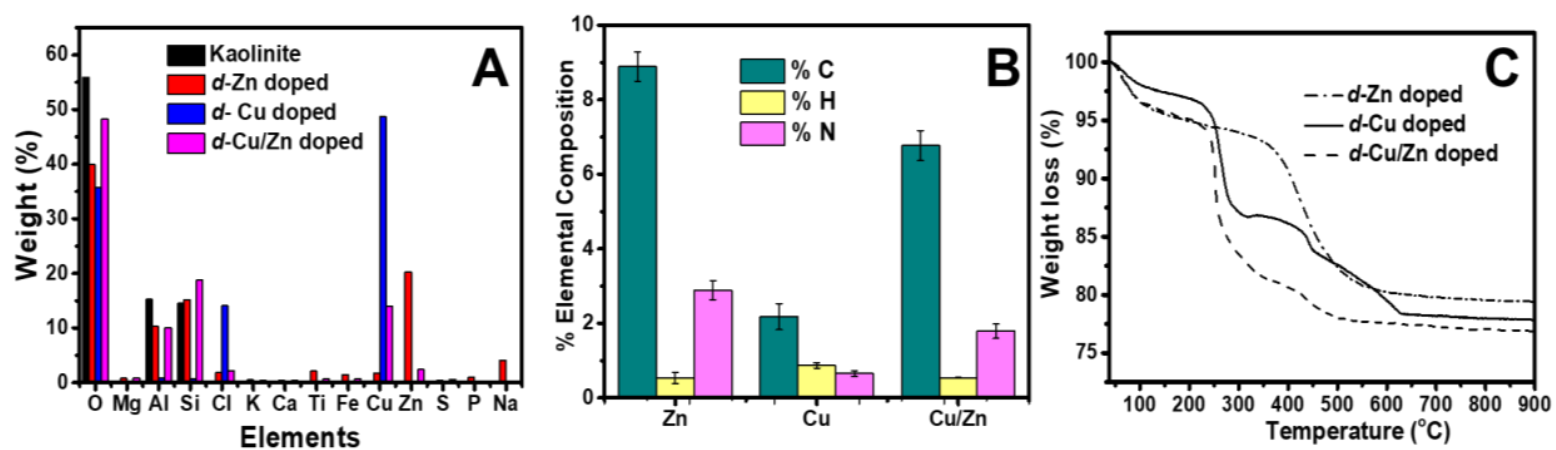

Fig. 6: (A) Energy Dispersive X-ray spectra of prepared kaolinite clay and prepared delaminated composites (B) Elemental Analysis of delaminated composites (C) Thermal Gravimetric Analysis of delaminated composites

To evaluate the thermal decomposition of the delaminated composite materials, thermogravimetric analysis (TGA) was carried out. Fig. 6C shows the TGA curves of the delaminated composite materials. Both $d-\mathrm{Zn}$ and $d-\mathrm{Cu} / \mathrm{Zn}$ doped photocatalytic composites show three-step weight loss consistent with loss of physisorbed water (40 to139 ${ }^{\circ} \mathrm{C}$ ), loss of volatiles $\left(139{ }^{\circ} \mathrm{C}\right.$ to $\left.352{ }^{\circ} \mathrm{C}\right)$, and volatilisation, thermal decomposition and degradation of the organic components of the composite material $\left(352{ }^{\circ} \mathrm{C}\right.$ to $\left.671{ }^{\circ} \mathrm{C}\right)[22,61]$. Interestingly, both composites show a total weight loss of $\sim 22 \%$ each while a TG analysis showed that Kaolinite used in this study had a total weight loss of $~ 9 \%$ [22]. However, $d$-Cu doped composite displayed a four-step weight loss with a total weight loss of $\sim 22 \%$. The fourth weight loss step occurring in the temperature range between $450{ }^{\circ} \mathrm{C}$ and $628{ }^{\circ} \mathrm{C}$ is due to phase transformation of $\mathrm{CuCl}_{2}$ to Copper oxides via pyrolysis [62]. All these results give concordant information about the chemical composition and morphologies of the composite materials. The simultaneous urea-induced delamination/metal impregnation steps successfully led to the formation of sheet-like composites with the formation of new crystal phases and surface defects that enhance the photoactivity of the composites in the visible region. 


\subsection{Photodisinfection of Water}

To test the efficiency of prepared composite materials for photodisinfection of water containing antibiotic-resistant bacteria, an MDR E. coli was used. Fig. S1 show the breakthrough times (the time it takes for the first bacteria colony to be observed in treated water) for the different composites. Their efficiency of $d$-Cu/Zn-doped composite was compared with its non-delaminated analogue- $f-\mathrm{Cu} / \mathrm{Zn}$ doped composite because it showed the highest breakthrough time.

The breakthrough times from the use of $2 \mathrm{~g}$ of prepared composites, to thoroughly disinfect water containing $2.16 \times 10^{7} \mathrm{cfu} / \mathrm{mL}$ of MDR E. coli in a fixed-bed set-up under visible-light from fluorescent lamps in the laboratory are: $660 \mathrm{~min}(11 \mathrm{~h})$ for $d$-Zn-doped composite, 1320 $\min (22 \mathrm{~h})$ for $d$-Cu-doped composite, $2160 \min (36 \mathrm{~h})$ for $d$-Cu/Zn-doped composite and $1200 \min (20 \mathrm{~h})$ for $f$-Cu/Zn-doped composite (Fig. S2 A-D). This implies that the $d$-Zndoped hybrid clay composite exhibits the lowest efficiency despite its highest surface area (Fig. S3, SI document). In contrast, $d$-Cu/Zn-doped composite presents the highest efficiency for the removal of this bacterial strain (MDR E. coli) from water. However, the delaminated composites showed improved efficiency over the furnace prepared composite $(f-\mathrm{Cu} / \mathrm{Zn}$-doped composite).

However, the higher disinfection efficiencies of $d$-Cu doped and $d$-Cu/Zn doped composites with respect to $d$-Zn doped does not follow the conventional principle that increased surface area should increase photoactivity (Fig. S3). It is reported that oxides of $\mathrm{Cu}$ are more toxic than that of $\mathrm{Zn}$, causing increased cytotoxicity and DNA damage [63-66]. There is also the possibility that other physical properties including photo-absorption property, solution $\mathrm{pH}$, crystalline content, exposed crystal facets (surface vacancies), and secondary particle size could control the photoactivity of these composites [67, 68]. 


\subsection{Re-growth of Multidrug-Resistant Bacteria}

Although, the ability of bacteria to grow in cultivation media (as observed in the cultured plates in Fig. S4 (supporting information document) may be lost after photocatalytic disinfection process due to damage from ROS activity, the potential of their repair and regrowth, within the necessary 'recuperation' time, should not be neglected. Bacteria re-growth has been reported to take place after water disinfection using various semiconductor photocatalysts [69]. Thus, in this study, the re-growth potential of MDR E. coli in treated water with the different prepared composite materials was studied. Wang et al. [24] did suggest recently that light conditions and storage temperature do influence the re-growth of bacteria in treated water. However, our results in this study, using our prepared composites, show that there is no re-growth of MDR E. coli in treated water even after 7 days either from incubation of treated water samples in the dark at $37{ }^{\circ} \mathrm{C}$ or while left standing under laboratory light conditions. However, this was only before the respective breakthrough times for the various composites. Bacteria colonies were found on plates of samples collected right after breakthrough times were exceeded (Table S1).

\subsection{Photodegradation of Antibiotic Resistance Genes}

It has been reported that cell membrane can be damaged via metal toxicity and the release of reactive oxygen species (ROS) from photocatalyst, could lead to the leakage of DNA contents of the bacteria (genes inclusive) into treated effluent. To establish this, necessary primers for the identification of various resistance genes for three class of antibiotics (Fluoroquinolones, Aminoglycoside and Sulphonamides) were applied to the samples. Only three ARGs: sul3 (confers resistance to sulphonamides), gyr B, and parE (confer resistance to Fluoroquinolones) were found in the MDR E. coli contaminated water used in this study. Based on this, treated water samples were collected at various time interval and these genes were identified using gel electrophoresis analysis following PCR amplification of the genes. Figs. 8A and 8B show 
results from gel electrophoresis analysis of MDR E. coli contaminated and treated water samples.

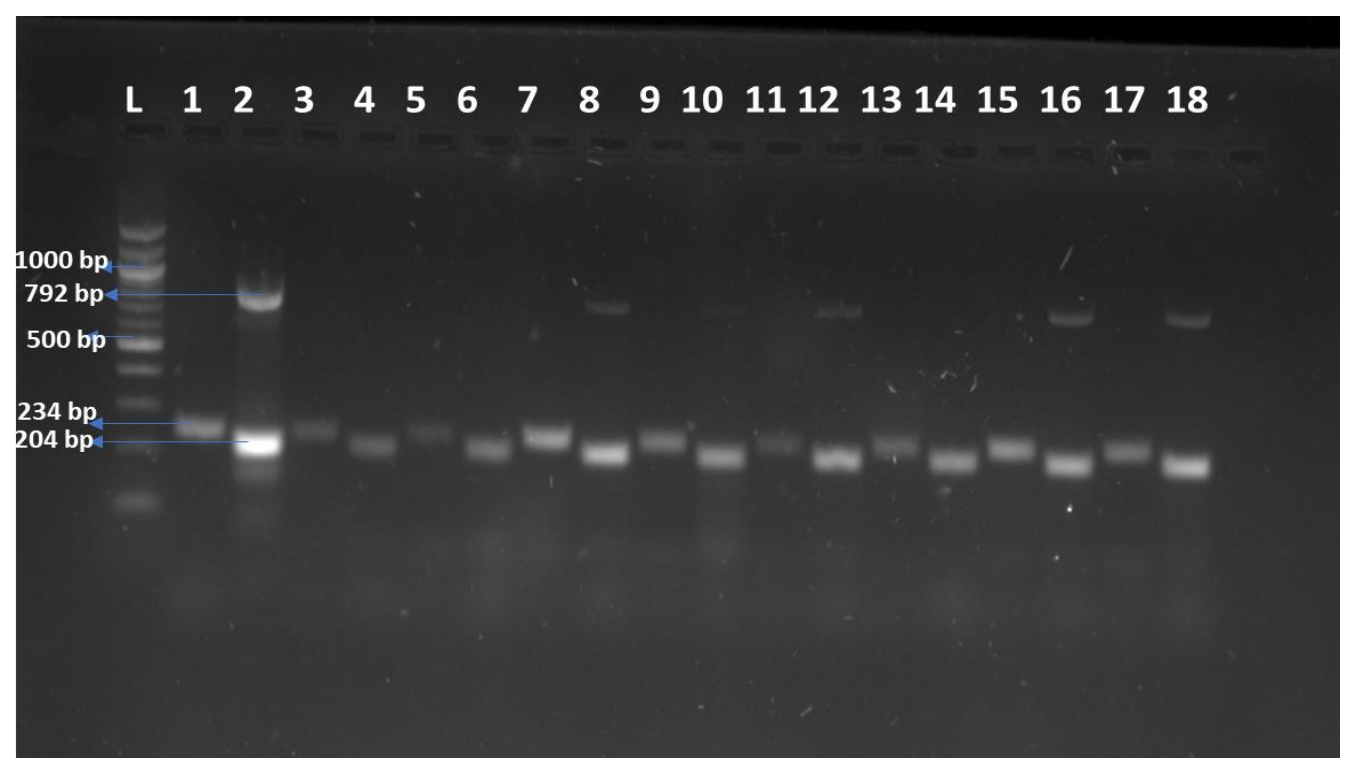

Fig. 8A: Agarose gel image of PCR-amplified products of water samples containing MDR $E$. coli and treated with $f$ - $\mathrm{Cu} / \mathrm{Zn}$ doped and $d$-Cu/Zn doped composites (gyr B gene-204bp, parE gene - 234bp, sul3 gene - 792bp).

Where,

L- 100bp Molecular Weight Marker

Lane 1 -Contaminated water showing parE gene

2 - Contaminated water showing gyrB \& sul3 genes

Lane $\quad 3-f-\mathrm{Cu} / \mathrm{Zn}$ doped treated $\mathrm{H}_{2} \mathrm{O}$ showing parE gene $4-f-\mathrm{Cu} / \mathrm{Zn}$ doped treated $\mathrm{H}_{2} \mathrm{O}$ showing gyrB gene $5-d-\mathrm{Cu} / \mathrm{Zn}$ doped treated $\mathrm{H}_{2} \mathrm{O}$ showing parE gene $6-d-\mathrm{Cu} / \mathrm{Zn}$ doped treated $\mathrm{H}_{2} \mathrm{O}$ showing gyr gene $\int$ of PC treatment

$7-f$-Cu/Zn doped treated $\mathrm{H}_{2} \mathrm{O}$ showing parE gene $8-f-\mathrm{Cu} / \mathrm{Zn}$ doped treated $\mathrm{H}_{2} \mathrm{O}$ showing $g y r \mathrm{~B} \&$ sul3 gene $9-d-\mathrm{Cu} / \mathrm{Zn}$ doped treated $\mathrm{H}_{2} \mathrm{O}$ showing parE gene $10-d-\mathrm{Cu} / \mathrm{Zn}$ doped treated $\mathrm{H}_{2} \mathrm{O}$ showing gyr $\mathrm{B}$ gene

Collected after $12 \mathrm{~h}$ of PC treatment

$11-f-\mathrm{Cu} / \mathrm{Zn}$ doped treated $\mathrm{H}_{2} \mathrm{O}$ showing parE gene $12-f$-Cu/Zn doped treated $\mathrm{H}_{2} \mathrm{O}$ showing $g y r \mathrm{~B} \&$ sul 3 genes $13-d-\mathrm{Cu} / \mathrm{Zn}$ doped treated $\mathrm{H}_{2} \mathrm{O}$ showing parE gene $14-d-\mathrm{Cu} / \mathrm{Zn}$ doped treated $\mathrm{H}_{2} \mathrm{O}$ showing gyrB gene

Collected after $20 \mathrm{~h}$ of PC treatment

$15-f-\mathrm{Cu} / \mathrm{Zn}$ doped treated $\mathrm{H}_{2} \mathrm{O}$ showing parE gene $16-f-\mathrm{Cu} / \mathrm{Zn}$ doped treated $\mathrm{H}_{2} \mathrm{O}$ showing $g y r \mathrm{~B} \&$ sul 3 gene $17-d-\mathrm{Cu} / \mathrm{Zn}$ doped treated $\mathrm{H}_{2} \mathrm{O}$ showing parE gene $18-d-\mathrm{Cu} / \mathrm{Zn}$ doped treated $\mathrm{H}_{2} \mathrm{O}$ showing gyr $\mathrm{B} \&$ sul3 genes

Collected after $36 \mathrm{~h}$ of PC treatment

Where PC $=$ photocatalytic 


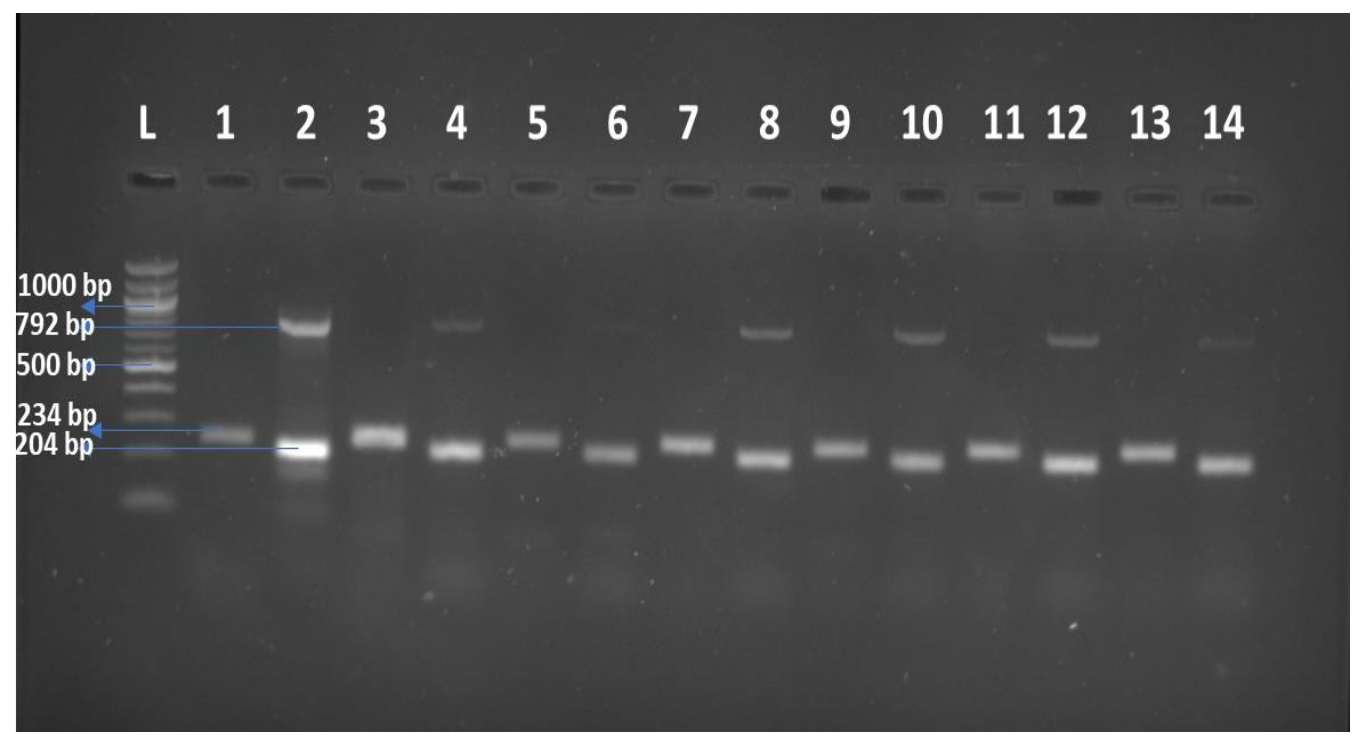

Fig. 8B: Agarose gel image of PCR-amplified products of water samples containing MDR $E$. coli and treated with $d-\mathrm{Zn}$ doped and $d$-Cu doped composites (gyrB gene $-204 \mathrm{bp}$, parE gene -234bp, sul3 gene - 792bp).

Where,

L- 100bp Molecular Weight Marker

Lane $\quad 1$ - Contaminated $\mathrm{H}_{2} \mathrm{O}$ showing parE gene

2 - Contaminated $\mathrm{H}_{2} \mathrm{O}$ showing gyrB \& sul3 genes

Lane $\quad 3-d$-Zn doped treated $\mathrm{H}_{2} \mathrm{O}$ showing parE gene $4-d$-Zn doped treated $\mathrm{H}_{2} \mathrm{O}$ showing gyr $\&$ sul3 genes $5-d$ - $\mathrm{Cu}$ doped treated $\mathrm{H}_{2} \mathrm{O}$ showing parE gene $6-d$ - $\mathrm{Cu}$ doped treated $\mathrm{H}_{2} \mathrm{O}$ showing gyr $\mathrm{B}$ gene

Collected after $6 \mathrm{~h}$ of PC treatment

$7-d-\mathrm{Cu}$ doped treated $\mathrm{H}_{2} \mathrm{O}$ showing parE gene $8-d$ - $\mathrm{Cu}$ doped treated $\mathrm{H}_{2} \mathrm{O}$ showing gyr $\mathrm{B} \&$ sul 3 gene $9-d-\mathrm{Zn}$ doped treated $\mathrm{H}_{2} \mathrm{O}$ showing parE gene $10-d$-Zn doped treated $\mathrm{H}_{2} \mathrm{O}$ showing gyr $\mathrm{B} \&$ sul 3 genes Collected after $15 \mathrm{~h}$ of PC treatment

$11-d-C u$ doped treated $\mathrm{H}_{2} \mathrm{O}$ showing parE gene $12-d-\mathrm{Cu}$ doped treated $\mathrm{H}_{2} \mathrm{O}$ showing gyr $\&$ sul3 gene $13-d-\mathrm{Zn}$ doped treated $\mathrm{H}_{2} \mathrm{O}$ showing parE gene $14-d$ - $\mathrm{Zn}$ doped treated $\mathrm{H}_{2} \mathrm{O}$ showing gyr $\mathrm{B}$ \& sul3 genes

Collected after $20 \mathrm{~h}$ of PC treatment

Where $\mathrm{PC}=$ photocatalytic

From the gel images in Fig. 8A, the first $7 \mathrm{~h}$ of photocatalytic treatment of contaminated water using $f$-Cu/Zn doped composite removed sul3 gene (sulphonamide resistance gene) implying that, within this time frame, the photocatalytic composite material is able to fragment the sul3 gene completely. Beyond this time $(8-30 \mathrm{~h})$, the sul3 gene remains in the treated water although with less intense band suggesting a decrease in the amount of this gene in the treated 
water (Lanes 8, 11, 12, 16, Fig. 8A). However, for water samples treated with $d$-Cu/Zn doped composite, the sul3 gene was not seen in them until after its breakthrough time of $36 \mathrm{~h}$ (Lane 18, Fig. 8A). In contrast, the $d$-Zn doped composite (Fig. 8B) showed traces of this gene in the treated water for all treatment times. Even though for $d-\mathrm{Cu}$ doped composite, the sul3 gene was removed from treated water within the first $7 \mathrm{~h}$, it is present in all treated water samples after this time.

Nonetheless, all photocatalytic composites used in this study were ineffective in completely removing parE and $g y r \mathrm{~B}$ genes (Fluoroquinolones resistance genes) from treated water for all treatment times. However, the fading intensity of bands for both genes may relate to a decrease in the quantity of these genes in the treated water. To ascertain this, there is a need for further studies to quantify these genes in the treated water for the various times.

\subsection{Two-Step Photocatalytic Disinfection Process}

Researchers have reported the incomplete removal of ARGs from water. For example, Karaolia et al. [19] reported the persistence of sul1 and ermB resistance genes throughout the photocatalytic treatment using graphene-based $\mathrm{TiO}_{2}$ composite [38]. However, in a bid to achieve complete photo-disinfection of MDR E. coli and its associated genes in this study, a second photo-disinfection step is proposed. In this case, after the first photo-disinfection step, the treated effluent is passed through another fixed-bed loaded with the same composite material to effect the complete removal of the total DNA content in the water.

As earlier reported in this study, among the composite materials used for the inactivation of MDR E. coli with its associated genes, the $d$-Cu/Zn-doped composite outperformed the other composite materials with a breakthrough time of $36 \mathrm{~h}$ and complete removal of sul3 gene from water up till this breakthrough time. Therefore, the $d-\mathrm{Cu} / \mathrm{Zn}$ doped composite is utilised for the two-step disinfection process. Figure 9 shows the gel electrophoresis image of ARGs 
present in water after treatment with $d-\mathrm{Cu} / \mathrm{Zn}$ doped composite. As expected, in the first photo-disinfection step, no band of the sulfonamides resistance gene (793 bp) was observed in the treated effluent until the $36^{\text {th }}$ hour. Yet, the fluoroquinolone resistance genes ( $g y r B-204$ bp and parE-234 bp) are seen in all samples collected during the first photo-disinfection step. However, in the second photo-disinfection step, the fluoroquinolone resistance genes (gyrB and parE) were still present in the treated water but in reduced amounts, as can be seen from their faded bands in the images in Fig. 9.

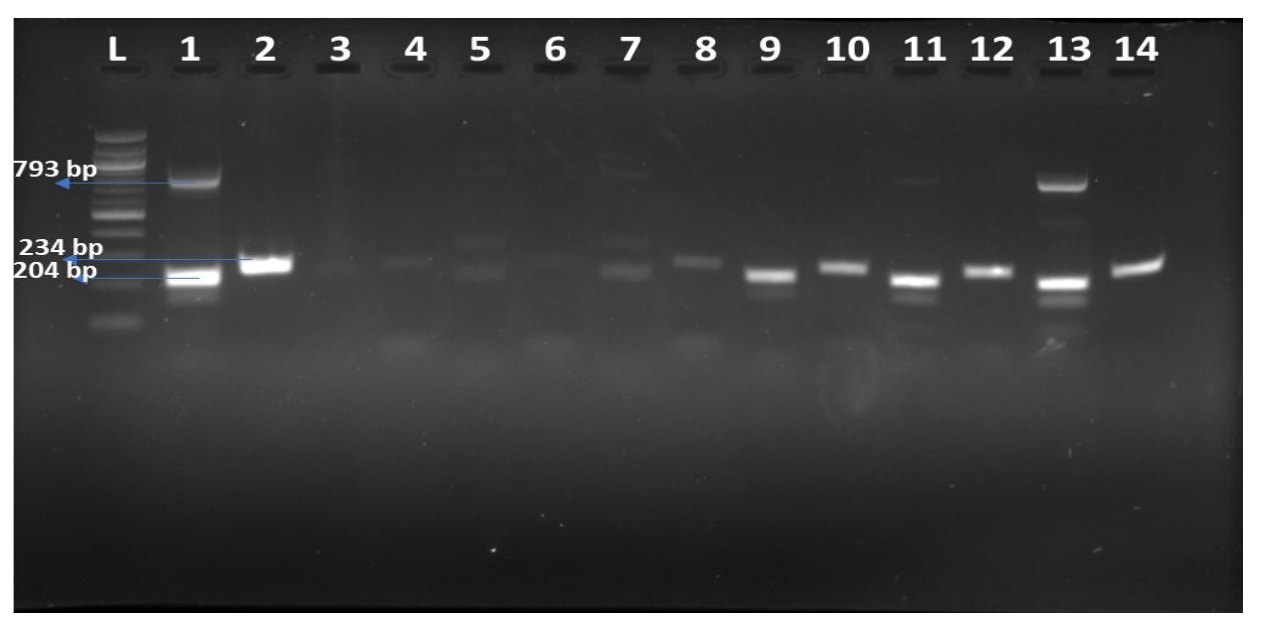

Fig. 9: Electrophoresis gel image of PCR-amplified products for a two-step treatment of water samples containing MDR $E$. coli with $d-\mathrm{Cu} / \mathrm{Zn}$ doped composite.

Where

L- 100bp Molecular Weight Marker

Lane 1 -Contaminated water showing gyrB \& sul3 genes

2 - Contaminated water showing parE gene

Lane

3 - 2nd treatment $d$ - $\mathrm{Cu} / \mathrm{Zn}$ doped treated $\mathrm{H}_{2} \mathrm{O}$ showing parE gene

$4-2$ nd treatment $d-\mathrm{Cu} / \mathrm{Zn}$ doped treated $\mathrm{H}_{2} \mathrm{O}$ showing gyr $\mathrm{B}$ gene

Collected after $6 \mathrm{~h}$

of PC treatment

5 - 2nd treatment $d$-Cu/Zn doped treated $\mathrm{H}_{2} \mathrm{O}$ showing parE and gyr $\mathrm{B}$ genes

6 - 2nd treatment $d$ - $\mathrm{Cu} / \mathrm{Zn}$ doped treated $\mathrm{H}_{2} \mathrm{O}$ showing gyr $\mathrm{B}$ gene

Collected

after $15 \mathrm{~h}$ of

7 - 2nd treatment $d$ - $\mathrm{Cu} / \mathrm{Zn}$ doped treated $\mathrm{H}_{2} \mathrm{O}$ showing gyr $\mathrm{B}$

8 - 2nd treatment $d$ - $\mathrm{Cu} / \mathrm{Zn}$ doped treated $\mathrm{H}_{2} \mathrm{O}$ showing parE gene $\}$ Collected after $30 \mathrm{~h}$

PC treatment

9 - 1st treatment $d$-Cu/Zn doped treated $\mathrm{H}_{2} \mathrm{O}$ showing gyr B gene

10 - 1st treatment $d$ - $\mathrm{Cu} / \mathrm{Zn}$ treated $\mathrm{H}_{2} \mathrm{O}$ showing parE gene

Collected after $6 \mathrm{~h}$

of PC treatment

11 - 1st treatment $d$-Cu/Zn doped treated $\mathrm{H}_{2} \mathrm{O}$ showing gyr $\mathrm{B}$ gene 
12 - 1st treatment $d-\mathrm{Cu} / \mathrm{Zn}$ doped treated $\mathrm{H}_{2} \mathrm{O}$ showing parE gene

13 - 1st treatment $d$ - $\mathrm{Cu} / \mathrm{Zn}$ doped treated $\mathrm{H}_{2} \mathrm{O}$ showing gyr $\mathrm{B}$ \& sul3 genes $14-1$ st treatment $d$ - $\mathrm{Cu} / \mathrm{Zn}$ doped treated $\mathrm{H}_{2} \mathrm{O}$ showing parE gene

Collected after $36 \mathrm{~h}$ of PC treatment

Where PC $=$ photocatalytic

This suggests that the delaminated $\mathrm{Cu} / \mathrm{Zn}$-doped (being the best performing photocatalyst) is capable of thorough photo-disinfection of water contaminated with MDR E. coli strain with its sulphonamide resistance genes after a second photodisinfection step. Nevertheless, the complete removal of fluoroquinolone is more challenging although a second photodisinfection step, is sufficient to reduce their amounts in treated water significantly.
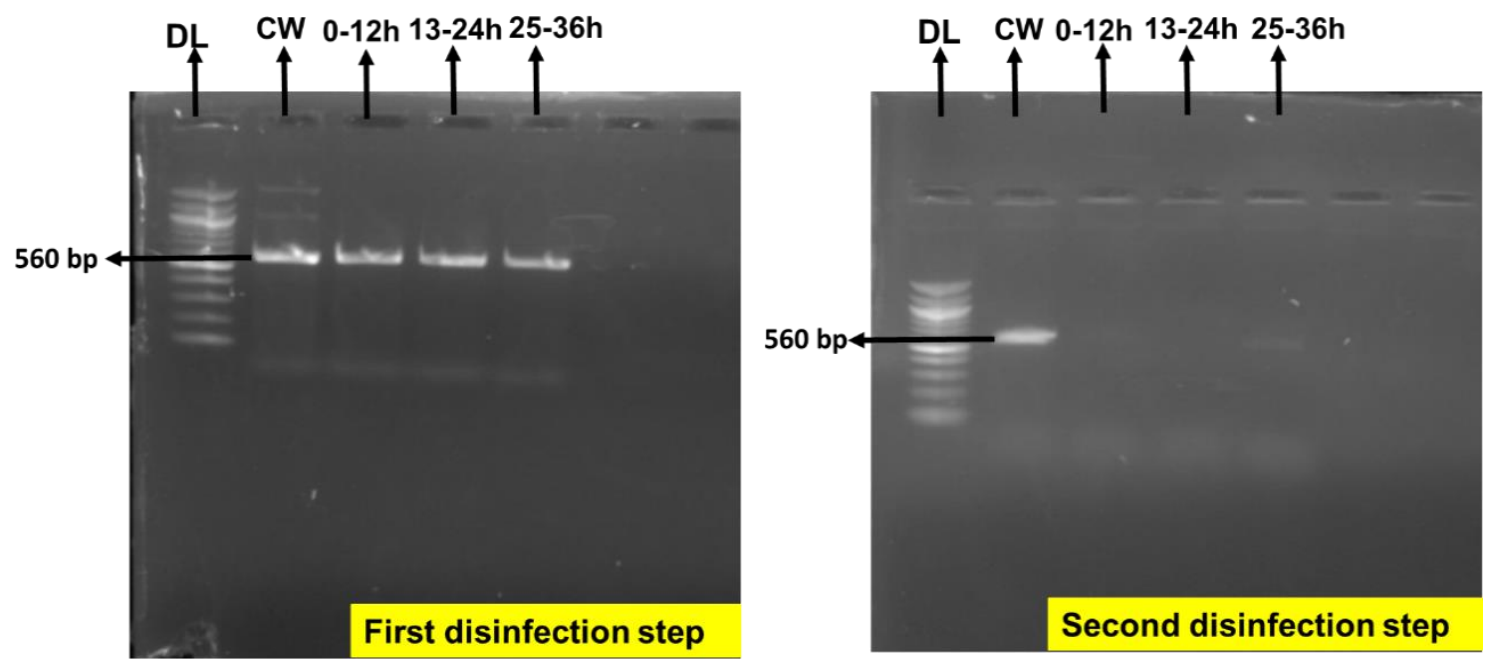

Fig. 10: Electrophoresis gel images of PCR-amplified Products of $16 \mathrm{~S}$ rRNA of water samples containing MDR $E$. coli treated with $d$-Cu/Zn doped $(\mathbf{D L}=$ Molecular Weight Marker; $\mathbf{C W}=$ contaminated water; $560 \mathrm{bp}=$ Unique Band for MDR E. coli)

The result from the 16S rRNA assay of both disinfection steps (Fig. 10) corroborates what was obtained from the two-step photo disinfection process in Fig. 9 with a faint band at 25-36 $\mathrm{h}$ still suggesting the presence of antibiotic resistance genes in the treated water after the second photodisinfection step.

\subsection{Mechanism of Photodisinfection}




\subsubsection{Release of Reactive Oxygen}

While it is interesting to know that our delaminated composite materials are efficient in removing $\mathrm{ARB}$ and $\mathrm{ARGs}$ from water, it is essential to find out how this occurs. In photocatalysis, it is general knowledge that reactive oxygen species $\left(\mathrm{O}_{2}^{--},{ }^{1} \mathrm{O}_{2}, \mathrm{HO}\right)$ are important for photodegradation to occur via lysing of bacteria cells that leads to cell death. In this study, we decided to check for superoxide radical $\left(\mathrm{O}_{2}^{-}\right)$in our delaminated composite materials as a possible radical responsible for their photodisinfection activity, using Nitroblue tetrazolium (NBT). We followed the generation of a bright blue stable product, formazan, both in the dark and in the light. Results presented in Fig. 11A-B suggests in relative terms that higher amounts of superoxide radicals were produced by $d-\mathrm{Cu}$ doped and $d$ - $\mathrm{Cu} / \mathrm{Zn}$ doped composites with the latter showing a consistently higher amount released over a more extended period in both light and dark systems. However, $d$-Zn doped composite released the lowest amounts of the superoxide radical under both light and dark conditions as expected. This trend $(d-\mathrm{Cu} / \mathrm{Zn}$ doped $>d$-Cu doped $>d-\mathrm{Zn}$ doped $)$ is consistent with their efficiency for photodisinfection of water, as shown in Fig. S1 (SI document).
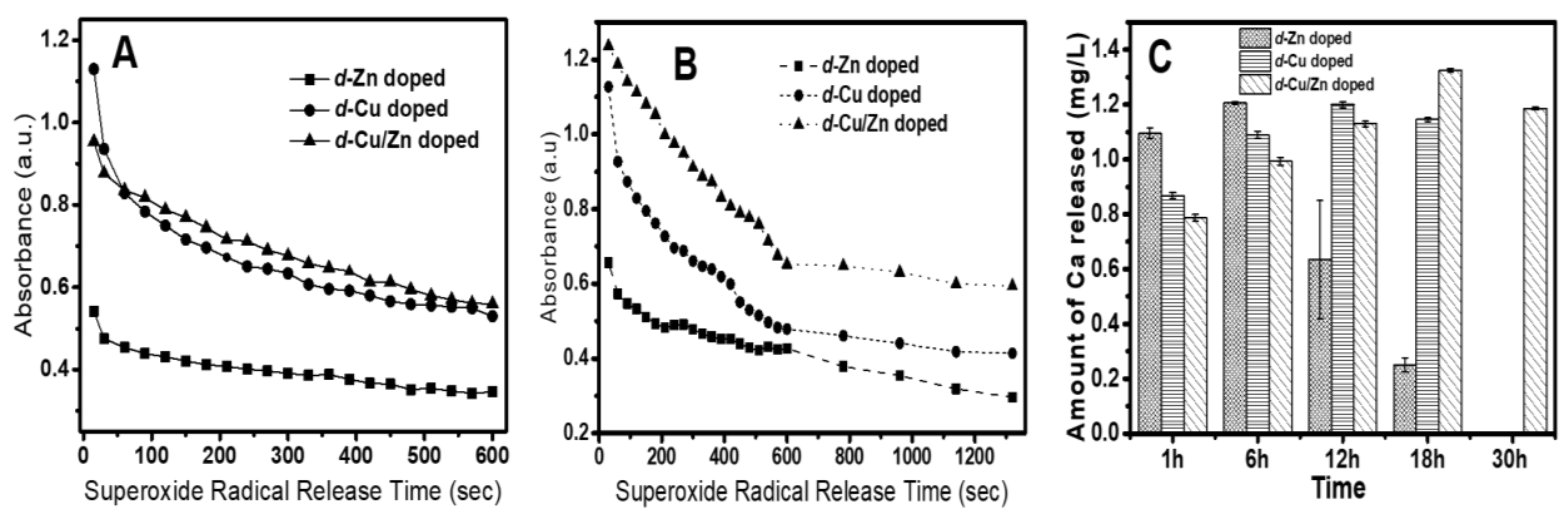

Fig. 11: Superoxide release profile (A) in the dark (B) in the light by delaminated photocatalytic composite materials; (C) Amount of $\mathrm{Ca}^{2+}$ released into treated water by lysed MDR E. coli Cells. The error bars represent standard deviation of replicates $(\mathrm{n}=2)$

Although the amount of superoxide released in the light is higher than in the dark (Fig. 11A and B), it is suggestive that these delaminated composites have the potentials of photo- 
disinfecting water in opaque systems. It has been shown that reactive oxygen species (particularly $\mathrm{O}_{2}^{-}$), facilitated by the presence of surface defects like oxygen vacancies, can be generated in the dark, for antibacterial activity [70]. To confirm disinfection in the dark via these delaminated composites, the most efficient composite ( $d$ - $\mathrm{Cu} / \mathrm{Zn}$ doped) was used to disinfect $1.1 \times 10^{9} \mathrm{cfu} / \mathrm{mL}$ MDR E. coli in dark and light conditions via a batch mode. Results confirm effective disinfection in the dark although much less than in the light (Fig. 12A). The various steps involved in the photodegradation of MDR E. coli via superoxide radical as shown in equations 4-8 [70-73][74].

$\mathrm{O}_{2}+e^{-} \rightarrow \mathrm{O}_{2}^{-}$

$\mathrm{O}_{2}^{--}+\mathrm{H}_{2} \mathrm{O} \rightarrow \mathrm{HO}_{2}+\mathrm{OH}^{-}$

$\mathrm{HO}_{2}+\mathrm{HO}_{2} \rightarrow \mathrm{H}_{2} \mathrm{O}_{2}+\mathrm{O}_{2}$

$\mathrm{H}_{2} \mathrm{O}_{2}+\mathrm{O}_{2}^{-} \rightarrow \mathrm{O}_{2}+\mathrm{HO}^{\cdot}+\mathrm{OH}^{-}$

$\mathrm{HO}+\mathrm{MDR}$. coli $\rightarrow \mathrm{CO}_{2}+\mathrm{H}_{2} \mathrm{O}+$ inorganic/organic by-products

Besides, there is evidence of photocatalytic harvesting and storing of light as long-lived trapped electrons which can be used for redox chemistry in the dark [75]. In addition to these, we believe that the release of metal ions into water (as will be discussed shortly) do also contribute to photodisinfection in the dark.

In the course of photodegradation, there is the possibility of bacteria being mineralized. To establish the photo-mineralisation effect of the composites, the treated water from the most efficient photocatalytic composite $(d-\mathrm{Cu} / \mathrm{Zn}$ doped $)$ was analysed for the amount of total carbon using the Total Organic Carbon analyser. Fig. 12 indicates that bacteria photomineralisation (inclusive of the genes) was as high as $95 \%\left(2.05 \times 10^{7} \mathrm{cfu} / \mathrm{mL}\right.$ of $2.19 \times 10^{7}$ $\mathrm{cfu} / \mathrm{mL}$ ) after both first and second disinfection stages of the bacterial loaded water but was $\geq$ $78 \%\left(1.6 \times 10^{7} \mathrm{cfu} / \mathrm{mL}\right)$ throughout the $30 \mathrm{~h}$ treatment period. 

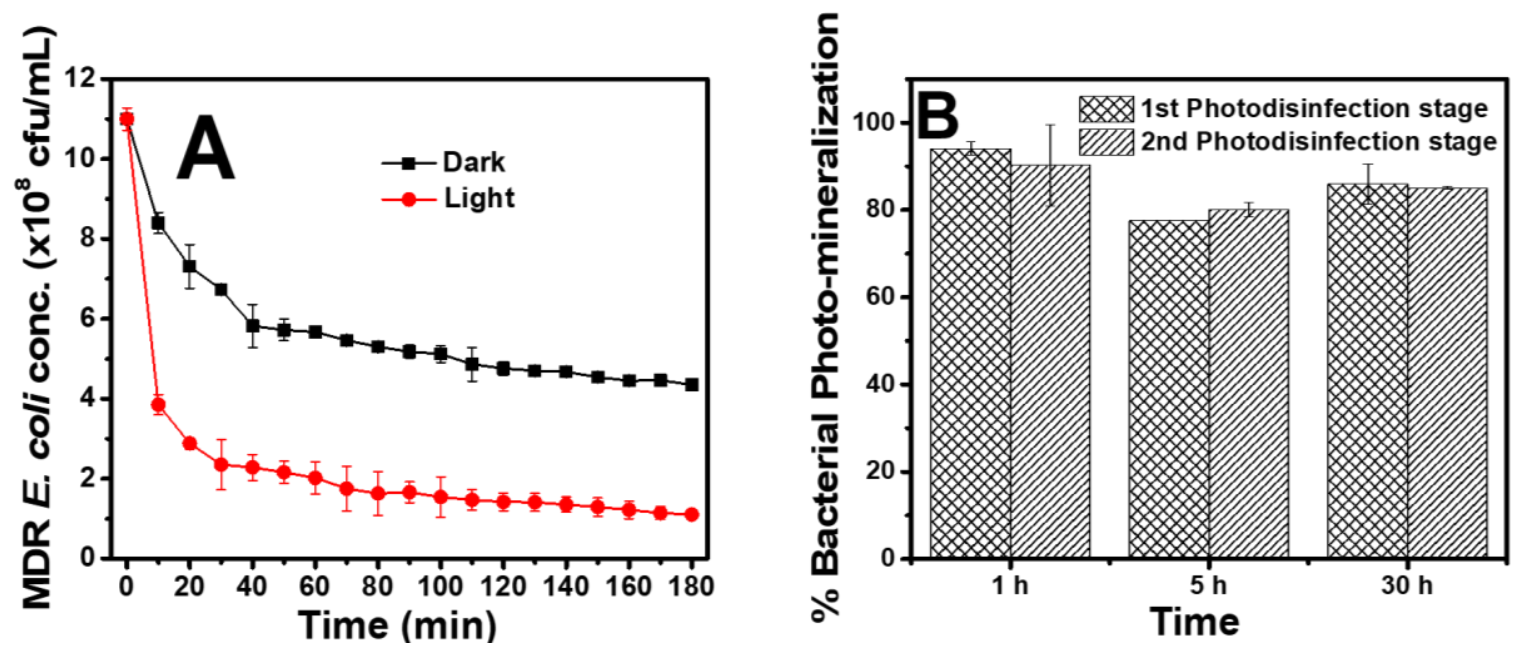

Fig. 12: (A) Photodegradation of MDR E. coli in the dark and in the light by $d$-Cu/Zn doped photocatalytic composite using batch mode [initial colony count $=1.1 \times 10^{9} \mathrm{cfu} / \mathrm{mL}$ ] (B) Photo-mineralisation profile of MDR E. coli treated water [initial colony count $=2.16 \times 10^{7}$ $c f u / m L]$ by $d-\mathrm{Cu} / \mathrm{Zn}$ doped photocatalytic composite using fixed bed mode. The error bars represent standard deviation of replicates $(n=2)$

In support of lysis of MDR E. coli bacteria cells via these composites, we measured the amount of $\mathrm{Ca}^{2+}$ released by dead bacteria cells into treated water since $\mathrm{Ca}^{2+}$ present in bacteria cells [76] are one of the several contents that will be released into the treated water by the dead bacteria cells. The increased concentration of $\mathrm{Ca}^{2+}$ from $0.061 \mathrm{mg} / \mathrm{L}$ in sterile water to $>1.0 \mathrm{mg} / \mathrm{L}$ in treated water, signifies the fact that bacteria cells were lysed during photocatalytic treatment. While the bacteria lysing strength of $d$-Zn doped composite tend to diminish especially at the $18^{\text {th }}$ hour (beyond its breakthrough time of $11 \mathrm{~h}$ when bacteria cells are longer lysed), that of $d-\mathrm{Cu}$ doped and $d-\mathrm{Cu} / \mathrm{Zn}$ doped composite were generally on the increase with that of $\mathrm{d}-\mathrm{Cu} / \mathrm{Zn}$ doped composite decreasing slightly to ca. $1.1 \mathrm{mg} / \mathrm{L}$ at $30 \mathrm{~h}$ (Fig. 11C). This level of $\mathrm{Ca}^{2+}$ does not pose any risk to life primarily because $\mathrm{Ca}^{2+}$ in drinking water does provide some health benefit including its function in body metabolism, serving as a signal for vital physiological processes, including vascular contraction, blood clotting, muscle 
contraction and nerve transmission [77]. The levels of calcium in treated water in this present work are still far below 2011 WHO standard limits of $75 \mathrm{mg} / \mathrm{L}$.

\subsubsection{Metal Toxicity}

There is the possibility that composite materials prepared with transition metal salts slowly release these metal ions into aqueous solution. Although some of these metals are essential for intracellular function in small quantities, yet they become very harmful at high concentrations. They can disrupt cellular membranes and cause cell death. In essence, metal toxicity is a likely mechanism for disinfection of MDR $E$. coli in water using $d-\mathrm{Cu} / \mathrm{Zn}$ doped photocatalytic composite.

To ascertain the release of these metals from the prepared composite materials into treated water and the bactericidal effect of these metals, sterile water and water contaminated with MDR E. coli were passed through the different composites loaded in a fixed-bed. Effluent from the fixed-bed, collected at different time intervals, were analysed for $\mathrm{Zn}$ and $\mathrm{Cu}$ using ICP-MS.
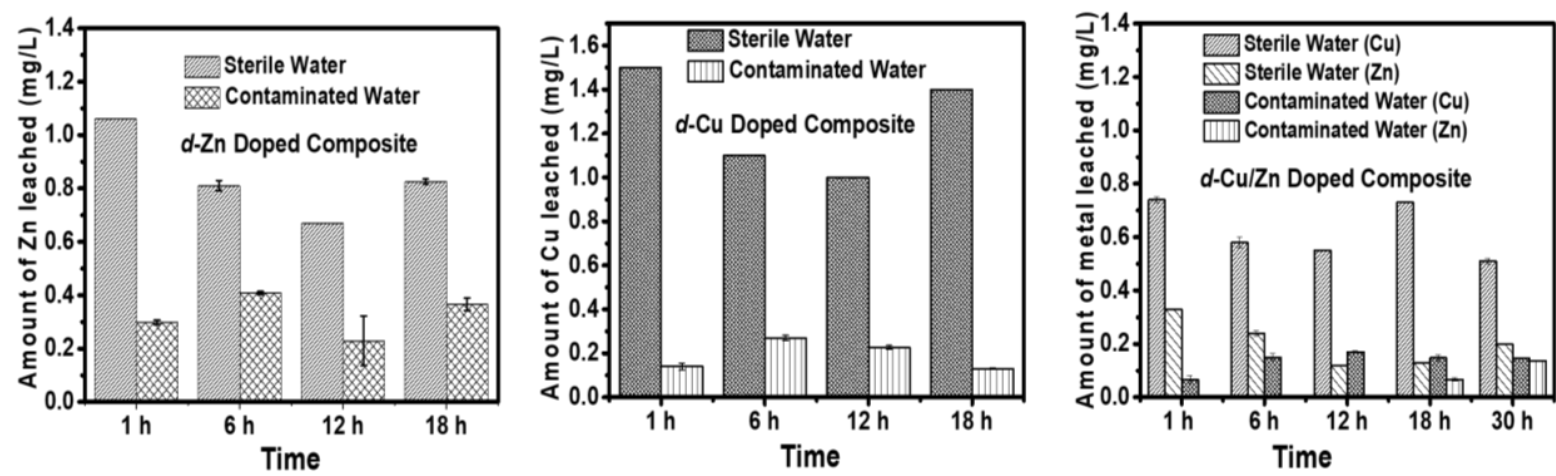

Fig. 13: Metal leaching analysis of photocatalytic composite materials at various times during photo-disinfection of water. The error bars represent standard deviation of replicates $(n=2)$

From the results presented in Fig 13, it is evident that the MDR E. coli could have picked up $\mathrm{Zn}$ and $\mathrm{Cu}$ ions in the water shortly before it passed through the photocatalyst in the fixed-bed.

This assumption is based on the fact that there was a significant decrease in the amount of 
metal ions in the treated water compared with that of sterile water when they were both passed through the fixed-beds containing each of the prepared composites. This (the ability to take in metal ions) is capable of causing bacterial cell death, and these biocidal-killed bacteria can go ahead to kill living bacteria in the same system through a mechanism called the "zombie effect". This effect is explained to mean that biocidal-killed bacteria, acting as a reservoir for the toxic metal, do kill living bacteria by releasing the toxic metal in them into their local environment including if they are also found in water [78]. As earlier mentioned as can be seen from Fig. 13, oxides of $\mathrm{Cu}$ have higher toxicity/g of the photocatalytic composite compared with oxide of $\mathrm{Zn} \mathrm{[63]} \mathrm{which} \mathrm{explains} \mathrm{its} \mathrm{higher} \mathrm{disinfection} \mathrm{efficiency.}$

Nevertheless, the residual amount of $\mathrm{Cu}$ and $\mathrm{Zn}$ leached into treated water $(<0.5 \mathrm{mg} / \mathrm{L})$ are all below WHO 2011 guidelines for water quality, which prescribes $2.0 \mathrm{mg} / \mathrm{L}$ for $\mathrm{Cu}$ and 3.0 $\mathrm{mg} / \mathrm{L}$ for $\mathrm{Zn}$ drinking water. Besides, the metal ions present in these delaminated composites are known essential elements for humans. For example, $\mathrm{Cu}$ plays a vital role in the stabilisation of skin proteins, cross-linking of collagens and endothelial growth. At the same time, $\mathrm{Zn}$ is essential for collagen, production of antibody and cell propagation [60]. Ingesting treated water from this study is not likely to cause harm to man or animal.

\subsection{Stability of Delaminated Photocatalytic Composite Materials}

There are lots of studies on the regeneration and reuse of photocatalytic materials. Indeed in our previous study [22] we regenerated and reused our photocatalyst using steam regeneration. However, one important factor that will determine the future of visible-light photocatalysts is their shelf-life. We hypothesise that there is the possibility of the photocatalyst losing some of its efficiency while on the shelf. To test the efficacy of this hypothesis, we stored the best photocatalytic material $(d-\mathrm{Zn} / \mathrm{Cu}$ doped photocatalytic composite) prepared in this study and its non-delaminated form ( $f$-Cu/Zn doped photocatalytic composite) in three different storage 
containers: transparent, amber and dark. The rhodamine B dye was used to test the efficiency of these composite materials under normal daylight condition and in the dark.

From Fig. 14A-B, it is evident that the delaminated photocatalytic composite ( $d-\mathrm{Zn} / \mathrm{Cu}$ doped) prepared via microwave technique is more stable to the storage conditions it was subjected to especially within the first 4 months $\left(\leq 4 \%\right.$ efficiency loss). After the $4^{\text {th }}$ month of storage, the delaminated photocatalytic composite doubled its efficiency loss (up to $\approx 12 \%$ ).
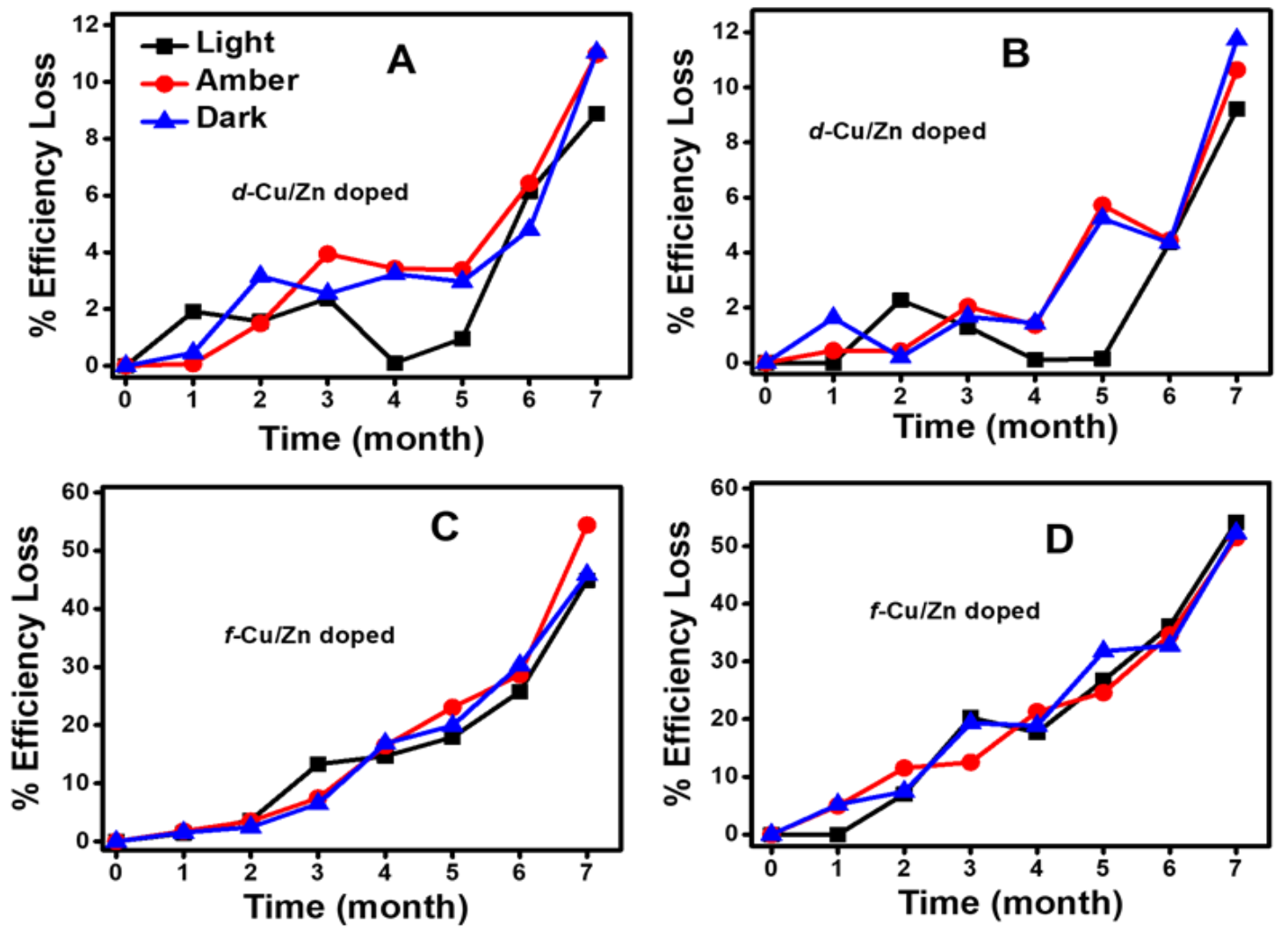

Fig. 14: Percentage efficiency loss for $d-\mathrm{Zn} / \mathrm{Cu}$ doped photocatalytic composite (A) under fluorescence illumination (B) in the dark; $f-\mathrm{Zn} / \mathrm{Cu}$ doped photocatalytic composite (C) under fluorescence illumination and (D) in the dark [weight of catalyst $=250 \mathrm{mg}$; volume $=50 \mathrm{~mL}$, initial conc. of $R h B$ dye $=10 \mathrm{mg} / \mathrm{L}$; time $=120 \mathrm{~min}]$.

However, with the non-delaminated photocatalytic composite $(f-\mathrm{Zn} / \mathrm{Cu}$ doped $)$ prepared via furnace, the loss of efficiency increased with increasing time and was as high as $55 \%$ after 7 months when the photocatalytic composite was tested on dye in the light and the dark (Fig. 14C-D). Nonetheless, the loss in efficiency of these composite materials was accompanied by a reduction in their rate of photodegradation of the dye (Fig. 15A-D). However, for both 
photocatalytic composite materials, storage conditions (light, amber and dark) had no significant effect on their efficacy. The same holds true for their rate of photodegradation.
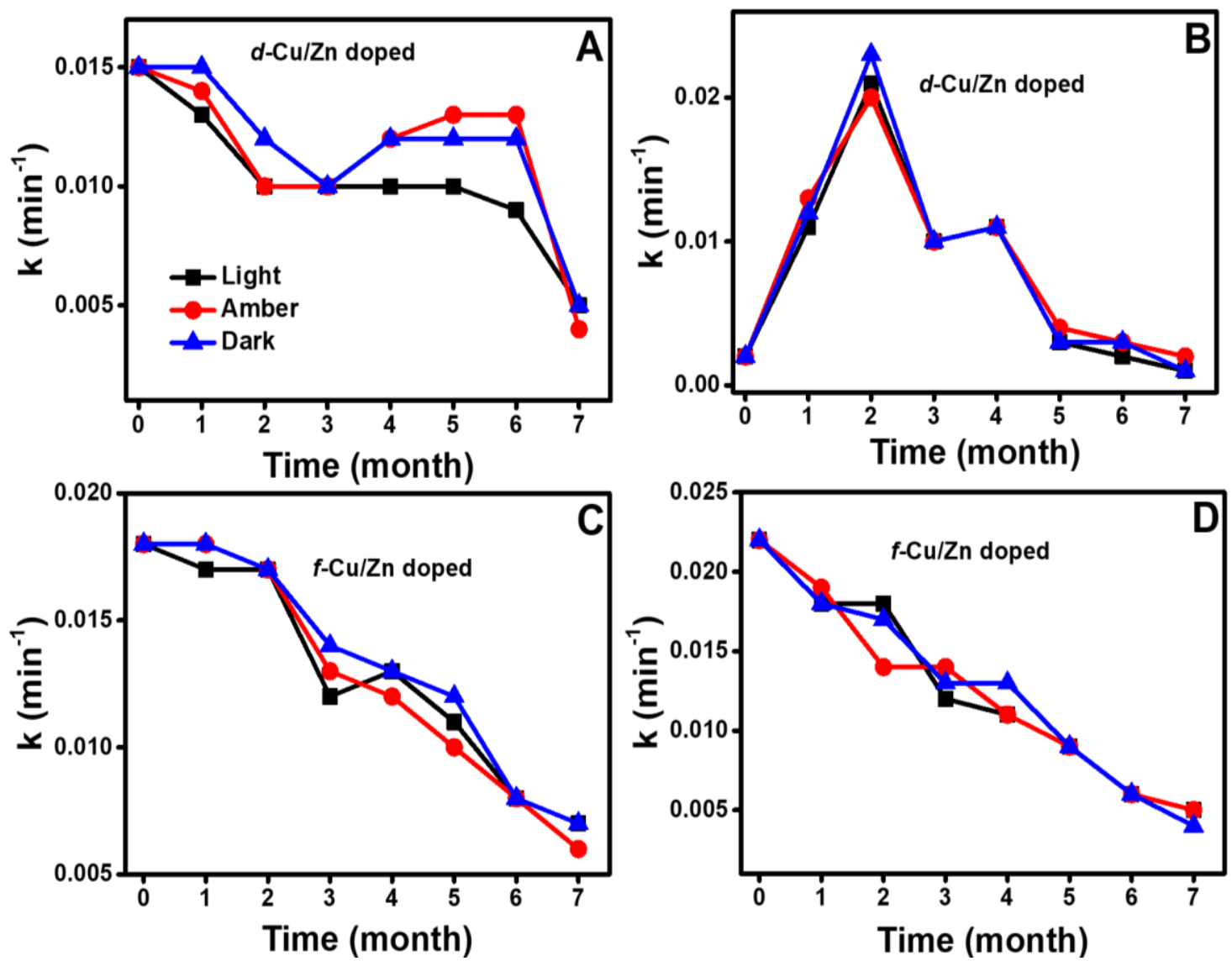

Fig. 15: Effect of storage conditions on the rate of photodegradation of Rhodamine $B$ dye using $\mathrm{Zn} / \mathrm{Cu}$-doped furnace $\left(\mathrm{N}_{2}\right)$ photocatalyst under $(\mathrm{A})$ illumination from fluorescent bulbs and (B) in the dark for 7 months [weight of catalyst $=250 \mathrm{mg}$; volume $=50 \mathrm{~mL}$, initial conc. of $\mathrm{RhB}$ dye $=10 \mathrm{mg} / \mathrm{L}$; time $=120 \mathrm{~min}]$.

\subsection{Conclusion}

The conclusions drawn from this research work can be summarised as follows:

- One-pot delamination and functionalisation of Kaolinite with urea, carica papaya seeds, $\mathrm{CuCl}_{2}$, and $\mathrm{ZnCl}_{2}$ provide a marked increase in its efficiency for photomineralisation of multidrug-resistant (MDR) bacteria under visible-light illumination.

- Scanning Electron Microscopy was used to confirm the presence of sheets in the delaminated composites. 
- At all experimental times, delaminated $\mathrm{Cu} / \mathrm{Zn}$-doped exhibited the highest breakthrough time (time for the first colony to appear in treated water) of $36 \mathrm{~h}$ thus indicating its superiority to other examined prepared composite- $d$-Zn doped (11 h) and $d$-Cu doped (22 h).

- Surface defects ( $\mathrm{Zn}$ and $\mathrm{Cu}$ vacancies, oxygen vacancies and interstitial $\mathrm{Zn}$ and $\mathrm{Cu}$ ) in the photocatalytic composites, identified through EPR and fluorescence spectroscopies, were found to play a role in the release of superoxide in the dark and in light conditions for photo-disinfection of MDR E. coli contaminated water. The release of the superoxide was consistent with the observed efficiencies of the composites

- Metal leaching into treated water was found to play a role that complements the release of superoxide for water photodisinfection process. Bacteria cell death was further confirmed through the release of $\mathrm{Ca}^{2+}$.

- The most efficient photocatalytic composite material ( $d$-Cu/Zn doped composite) was able to remove altogether, antibiotic-resistant bacteria of concentration and its associated sulphonamide resistance gene (sul3 gene) from $17.28 \mathrm{~L}$ of water contaminated with $2.16 \times 10^{7} \mathrm{cfu} / \mathrm{mL}$ of MDR E. coli after a first photodisinfection step that lasted $36 \mathrm{~h}$ using a fixed-bed.

- A second photo-disinfection step was able to reduce the amount of parE and gyrB genes (fluroquinolone resistance genes) significantly in the treated water even though they were persistent.

- As high as $95 \%$ photo-mineralisation (conversion of bacteria to $\mathrm{CO}_{2}$ and $\mathrm{H}_{2} \mathrm{O}$ ) of MDR E. coli bacteria was achieved with the most efficient photocatalytic composite material $(d-\mathrm{Cu} / \mathrm{Zn}$ doped composite) within the first $6 \mathrm{~h}$. However, this became stable at $\geq 78 \%$ after this time up till $30 \mathrm{~h}$ of photocatalytic treatment. 
- The shelf-life of the composites was determined under various storage conditions. The $d-\mathrm{Cu} / \mathrm{Zn}$ doped composite prepared with microwave furnace was far more stable to light and dark conditions within 7 months than the composite prepared in air using a regular furnace. Similarly, it was more stable to temperature variation than a typical furnace prepared composite. This has strong implication for the shelf-life of the photocatalyst especially if they have the potential to be utilised on a commercial scale.

- Delaminated composite in this study hold promise for water disinfection in systems that do not allow light into them.

\section{Acknowledgement}

The author, EIU, acknowledges with thanks, the Alexander von Humboldt Foundation for an equipment grant for the purchase of Fluorescence Spectrophotometer equipment used in this study. The authors EIU and CGU also acknowledge the support of Cambridge-Africa ALBORADA for financial support to carry out part of the characterization of photocatalytic samples at the University of Cambridge, United Kingdom. The authors, EIU, ODO and AO, acknowledge the support of The World Academy of Sciences-Islamic Development Bank (TWAS-IsDB) in the form of a research grant which was used to purchase some reagents used in this study. The authors also acknowledge the African Centre of Excellence for Genomics of Infectious Diseases (ACEGID), Redeemer's University, for support in carry out molecular analysis on treated water samples.

\section{References}

[1] L. Rizzo, C. Manaia, C. Merlin, T. Schwartz, C. Dagot, M. Ploy, I. Michael, D. Fatta-Kassinos, Science of the total environment 447 (2013) 345-360.

[2] C. Xi, Y. Zhang, C.F. Marrs, W. Ye, C. Simon, B. Foxman, J. Nriagu, Applied and environmental microbiology 75 (2009) 5714-5718.

[3] X. Huang, C. Liu, K. Li, F. Liu, D. Liao, L. Liu, G. Zhu, J. Liao, Environmental Science and Pollution Research 20 (2013) 9066-9074. 
[4] Z. Chen, D. Yu, S. He, H. Ye, L. Zhang, Y. Wen, W. Zhang, L. Shu, S. Chen, Frontiers in microbiology 8 (2017) 1133.

[5] T. Schwartz, W. Kohnen, B. Jansen, U. Obst, FEMS microbiology ecology 43 (2003) 325-335.

[6] I. Michael, L. Rizzo, C. McArdell, C. Manaia, C. Merlin, T. Schwartz, C. Dagot, D. Fatta-Kassinos, Water research 47 (2013) 957-995.

[7] N.L. Fahrenfeld, Y. Ma, M. O'Brien, A. Pruden, Frontiers in microbiology 4 (2013) 130.

[8] J. Bengtsson-Palme, E. Kristiansson, D.J. Larsson, FEMS microbiology reviews 42 (2018) fux053.

[9] Y. Ben, C. Fu, M. Hu, L. Liu, M.H. Wong, C. Zheng, Environmental research 169 (2019) 483493.

[10] A. White, J.M. Hughes, EcoHealth 16 (2019) 404-409.

[11] K. Slipko, D. Reif, M. Woegerbauer, P. Hufnagl, J. Krampe, N. Kreuzinger, Water Research 164 (2019) 114916.

[12] M.L. Luprano, M. De Sanctis, G. Del Moro, C. Di laconi, A. Lopez, C. Levantesi, Science of the Total Environment 571 (2016) 809-818.

[13] R. Zhang, T. Meng, C.-H. Huang, W. Ben, H. Yao, R. Liu, P. Sun, Environmental science \& technology 52 (2018) 7833-7841.

[14] Y. Yoon, M.C. Dodd, Y. Lee, Environmental Science: Water Research \& Technology 4 (2018) $1239-1251$.

[15] Y. Hu, T. Zhang, L. Jiang, S. Yao, H. Ye, K. Lin, C. Cui, Chemical Engineering Journal 368 (2019) 888-895.

[16] K.G. McGuigan, R.M. Conroy, H.-J. Mosler, M. du Preez, E. Ubomba-Jaswa, P. FernandezIbanez, Journal of hazardous materials 235 (2012) 29-46.

[17] A.J. Misra, S. Das, A.H. Rahman, B. Das, R. Jayabalan, S.K. Behera, M. Suar, A.J. Tamhankar, A. Mishra, C.S. Lundborg, Journal of colloid and interface science 530 (2018) 610-623.

[18] A. Rincón, C. Pulgarin, Applied Catalysis B: Environmental 44 (2003) 263-284.

[19] P. Karaolia, I. Michael-Kordatou, E. Hapeshi, C. Drosou, Y. Bertakis, D. Christofilos, G.S. Armatas, L. Sygellou, T. Schwartz, N.P. Xekoukoulotakis, Applied Catalysis B: Environmental 224 (2018) 810-824.

[20] E.I. Unuabonah, A. Adewuyi, M.O. Kolawole, M.O. Omorogie, O.C. Olatunde, S.O. Fayemi, C. Günter, C.P. Okoli, F.O. Agunbiade, A. Taubert, Heliyon 3 (2017) e00379.

[21] E.I. Unuabonah, M.O. Kolawole, F.O. Agunbiade, M.O. Omorogie, D.T. Koko, C.G. Ugwuja, L.E. Ugege, N.E. Oyejide, C. Günter, A. Taubert, Journal of environmental chemical engineering 5 (2017) 2128-2141.

[22] C.G. Ugwuja, O. Adelowo, A. Ogunlaja, M.O. Omorogie, O. Olukanni, O. Ikhimiukor, I. lermak, G. Kolawole, C. Guenter, A. Taubert, O. Bodede, R. Moodley, M.N. Inada, S.S.A. de Carmago, E.I. Unuabonah, ACS Applied Materials \& Interfaces 11 (2019) 25483-25494.

[23] S. Das, S. Sinha, B. Das, R. Jayabalan, M. Suar, A. Mishra, A.J. Tamhankar, C.S. Lundborg, S.K. Tripathy, Scientific reports 7 (2017) 1-14.

[24] M. Wang, M. Ateia, D. Awfa, C. Yoshimura, Chemosphere (2020) 128850.

[25] S. Das, A.J. Misra, A.H. Rahman, B. Das, R. Jayabalan, A.J. Tamhankar, A. Mishra, C.S.

Lundborg, S.K. Tripathy, Applied Catalysis B: Environmental 259 (2019) 118065.

[26] P.O. Nyangaresi, Y. Qin, G. Chen, B. Zhang, Y. Lu, L. Shen, Catalysis Today 335 (2019) 200-207.

[27] M.-T. Guo, X.-B. Tian, Journal of hazardous materials 380 (2019) 120877.

[28] H. Yin, G. Li, X. Chen, W. Wang, P.K. Wong, H. Zhao, T. An, Applied Catalysis B: Environmental (2020) 118829.

[29] G. Li, X. Liu, H. Zhang, P.-K. Wong, T. An, H. Zhao, Applied Catalysis B: Environmental 140 (2013) 225-232.

[30] N. Masoudipour, M. Sadeghi, F. Mohammadi-Moghadam, Desalination and Water Treatment 110 (2018) 109-116.

[31] S. Bharti, S. Mukherji, S. Mukherji, Science of The Total Environment 689 (2019) 991-1000. 
[32] J. Li, X. Zhang, F. Raziq, J. Wang, C. Liu, Y. Liu, J. Sun, R. Yan, B. Qu, C. Qin, Applied Catalysis B: Environmental 218 (2017) 60-67.

[33] P. Raizada, A. Sudhaik, S. Patial, V. Hasija, A.A.P. Khan, P. Singh, S. Gautam, M. Kaur, V.-H. Nguyen, Arabian Journal of Chemistry 13 (2020) 8424-8457.

[34] C.B. Ong, L.Y. Ng, A.W. Mohammad, Renewable and Sustainable Energy Reviews 81 (2018) 536-551.

[35] A.A. Bayode, E.M. Vieira, R. Moodley, S. Akpotu, A.S. de Camargo, D. Fatta-Kassinos, E.I. Unuabonah, Chemical Engineering Journal (2020) 127668.

[36] K.O. Adebowale, I.E. Unuabonah, B.I. Olu-Owolabi, Applied clay science 29 (2005) 145-148.

[37] Clinical, L.S. Institute, Performance standards for antimicrobial susceptibility testing, Clinical and Laboratory Standards Institute Wayne, PA, 2017.

[38] P. Karaolia, I. Michael-Kordatou, E. Hapeshi, C. Drosou, Y. Bertakis, D. Christofilos, G.S. Armatas, L. Sygellou, T. Schwartz, N.P.J.A.C.B.E. Xekoukoulotakis, 224 (2018) 810-824.

[39] M.O. Alfred, M.O. Omorogie, O. Bodede, R. Moodley, A. Ogunlaja, O.G. Adeyemi, C. Günter, A. Taubert, I. lermak, H. Eckert, Chemical Engineering Journal (2020) 125544.

[40] L. Niu, J.N. Coleman, H. Zhang, H. Shin, M. Chhowalla, Z. Zheng, Small 12 (2016) 272-293.

[41] V. Nicolosi, M. Chhowalla, M.G. Kanatzidis, M.S. Strano, J.N. Coleman, Science 340 (2013) 1226419.

[42] C. Engelbrekt, P. Malcho, J. Andersen, L. Zhang, K. Ståhl, B. Li, J. Hu, J. Zhang, Journal of nanoparticle research 16 (2014) 2562.

[43] J. Kong, S. Yu, Acta biochimica et biophysica Sinica 39 (2007) 549-559.

[44] P.K. Krivoshein, D.S. Volkov, O.B. Rogova, M.A. Proskurnin, Photoacoustics 18 (2020) 100162.

[45] E.I. Unuabonah, R. Nöske, J. Weber, C. Günter, A. Taubert, Beilstein journal of nanotechnology 10 (2019) 119-131.

[46] E. Unuabonah, B. Olu-Owolabi, K. Adebowale, A. Ofomaja, Colloids and surfaces A:

Physicochemical and engineering aspects 292 (2007) 202-211.

[47] W. Martens, R.L. Frost, P.A. Williams, Neues Jahrbuch für Mineralogie-Abhandlungen: Journal of Mineralogy and Geochemistry 178 (2003) 197-215.

[48] A. Bhaumik, A.M. Shearin, R. Patel, K. Ghosh, Physical Chemistry Chemical Physics 16 (2014) 11054-11066.

[49] A.K. Sasmal, S. Dutta, T. Pal, Dalton Transactions 45 (2016) 3139-3150.

[50] W. Xie, R. Li, Q. Xu, Scientific reports 8 (2018) 1-10.

[51] D. Galland, A.J.S.S.C. Herve, 14 (1974) 953-956.

[52] J. Lv, C. Li, J. BelBruno, CrystEngComm 15 (2013) 5620-5625.

[53] S.L. Reddy, T.J.T.o.t.M.R.S.o.J. Endo, 35 (2010) 423-429.

[54] L. Hu, J. Huang, H. He, L. Zhu, S. Liu, Y. Jin, L. Sun, Z. Ye, Nanoscale 5 (2013) 3918-3930.

[55] L.B. Hoch, P. Szymanski, K.K. Ghuman, L. He, K. Liao, Q. Qiao, L.M. Reyes, Y. Zhu, M.A. El-

Sayed, C.V. Singh, Proceedings of the National Academy of Sciences 113 (2016) E8011-E8020.

[56] W. Gehlhoff, D. Azamat, A. Hoffmann, Materials Science in Semiconductor Processing 6 (2003) 379-383.

[57] A.N. Pestryakov, V.P. Petranovskii, A. Kryazhov, O. Ozhereliev, N. Pfänder, A. Knop-Gericke, Chemical physics letters 385 (2004) 173-176.

[58] R. Bhargava, S. Khan, Journal of Physics: Condensed Matter 30 (2018) 335703.

[59] D. Chen, Z. Wang, T. Ren, H. Ding, W. Yao, R. Zong, Y. Zhu, The Journal of Physical Chemistry C 118 (2014) 15300-15307.

[60] M. Ashfaq, N. Verma, S. Khan, Materials Science and Engineering: C 59 (2016) 938-947.

[61] H. Cheng, Q. Liu, J. Liu, B. Sun, Y. Kang, R.L. Frost, Journal of Thermal Analysis and Calorimetry 116 (2014) 195-203.

[62] P. Deka, R.C. Deka, P. Bharali, New Journal of Chemistry 38 (2014) 1789-1793.

[63] U. Vicario-Parés, L. Castañaga, J.M. Lacave, M. Oron, P. Reip, D. Berhanu, E. Valsami-Jones, M.P. Cajaraville, A. Orbea, Journal of Nanoparticle Research 16 (2014) 1-16. 
[64] Q. Qin, J. Li, J. Wang, Water Environment Research 89 (2017) 378-383.

[65] C.-h. Wu, (2012).

[66] T.P. Dasari, K. Pathakoti, H.-M. Hwang, Journal of environmental sciences 25 (2013) 882-888.

[67] F. Amano, K. Nogami, M. Tanaka, B. Ohtani, Langmuir 26 (2010) 7174-7180.

[68] N.S. Allen, N. Mahdjoub, V. Vishnyakov, P.J. Kelly, R.J. Kriek, Polymer degradation and stability 150 (2018) 31-36.

[69] C.H.A. Tsang, H. Kwok, Z. Cheng, D.J.P.i.S.S.C. Leung, 45 (2017) 1-8.

[70] V. Lakshmi Prasanna, R. Vijayaraghavan, Langmuir 31 (2015) 9155-9162.

[71] M. Hayyan, M.A. Hashim, I.M. AlNashef, Chemical reviews 116 (2016) 3029-3085.

[72] Y. Xiao, L. Carena, M.-T. Näsi, A.V. Vähätalo, Water research 177 (2020) 115782.

[73] Y. Li, W. Zhang, J. Niu, Y. Chen, ACS nano 6 (2012) 5164-5173.

[74] R. Vijayaraghavan, Materials Science and Engineering: C 77 (2017) 1027-1034.

[75] V.W.h. Lau, D. Klose, H. Kasap, F. Podjaski, M.C. Pignié, E. Reisner, G. Jeschke, B.V. Lotsch, Angewandte Chemie 129 (2017) 525-529.

[76] D.C. Dominguez, Molecular microbiology 54 (2004) 291-297.

[77] J.A. Cotruvo, J. Bartram, Calcium and magnesium in drinking-water: public health significance, World Health Organization, 2009.

[78] R.B.-K. Wakshlak, R. Pedahzur, D. Avnir, Scientific reports 5 (2015) 9555. 